\title{
Denitrification in an oligotrophic estuary: a delayed sink for riverine nitrate
}

\author{
Dana Hellemann ${ }^{1, *}$, Petra Tallberg ${ }^{1}$, Ines Bartl ${ }^{2}$, Maren Voss ${ }^{2}$, Susanna Hietanen ${ }^{1}$ \\ ${ }^{1}$ Department of Environmental Sciences, University of Helsinki, 00014 Helsinki, Finland \\ ${ }^{2}$ Department of Biological Oceanography, Leibniz Institute for Baltic Sea Research Warnemünde, 18119 Rostock, Germany
}

\begin{abstract}
Estuaries are often seen as natural filters of riverine nitrate, but knowledge of this nitrogen sink in oligotrophic systems is limited. We measured spring and summer dinitrogen production (denitrification, anammox) in muddy and non-permeable sandy sediments of an oligotrophic estuary in the northern Baltic Sea, to estimate its function in mitigating the riverine nitrate load. Both sediment types had similar denitrification rates, and no anammox was detected. In spring at high nitrate loading, denitrification was limited by likely low availability of labile organic carbon. In summer, the average denitrification rate was $\sim 138 \mu \mathrm{mol} \mathrm{N} \mathrm{m}{ }^{-2} \mathrm{~d}^{-1}$. The corresponding estuarine nitrogen removal for August was $\sim 1.2 \mathrm{t}$, of which $~ 93 \%$ was removed by coupled nitrification-denitrification. Particulate matter in the estuary was mainly phytoplankton derived ( $>70 \%$ in surface waters) and likely based on the riverine nitrate which was not removed by direct denitrification due to water column stratification. Subsequently settling particles served as a link between the otherwise uncoupled nitrate in surface waters and benthic nitrogen removal. We suggest that the riverine nitrate brought into the oligotrophic estuary during the spring flood is gradually, and with a time delay, removed by benthic denitrification after being temporarily 'trapped' in phytoplankton particulate matter. The oligotrophic system is not likely to face eutrophication from increasing nitrogen loading due to phosphorus limitation. In response, coupled nitrification-denitrification rates are likely to stay constant, which might increase the future export of nitrate to the open sea and decrease the estuary's function as a nitrogen sink relative to the load.
\end{abstract}

KEY WORDS: Coastal filter - Northern Baltic Sea $\cdot$ Nitrogen $\cdot$ Sand sediment $\cdot$ Particulate organic nitrogen $\cdot$ Isotope pairing technique $\cdot$ Quark Strait

\section{INTRODUCTION}

Estuarine ecosystems are transition zones where fresh and marine waters meet. The different physical, chemical and biological characteristics of the 2 water bodies form a dynamic environment where water column stratification (Dyer 1973) and intense elemental cycling (Nedwell et al. 1999) occur. Estuaries are regarded as important natural filters of the land-derived, riverine load of nutrients, sediment and organic matter on its way to the open sea (Nedwell et al. 1999, Dürr et al. 2011). A significant part of this load is processed in the upper sediments, which

${ }^{*}$ Corresponding author: dana.hellemann@helsinki.fi thus play a key role in estuarine biogeochemical element cycling (Jørgensen \& Sørensen 1985, Jørgensen \& Revsbech 1989).

Nitrate $\left(\mathrm{NO}_{3}^{-}\right)$is abundant in many river waters. It is primarily anthropogenic in origin due to sewage waters and its extensive use as a fertilizer in agriculture within river catchment areas (Nixon 1995, Howarth et al. 1996). Wash-out of excess $\mathrm{NO}_{3}{ }^{-}$carries the nutrient into ground, river and eventually estuarine waters, where it frequently leads to eutrophication (Nixon 1995) with far-reaching consequences for the ecosystem, such as oxygen $\left(\mathrm{O}_{2}\right)$ deficiency of bottom waters (Diaz \& Rosenberg 2008). Nitrogen (N) is

() The authors 2017. Open Access under Creative Commons by Attribution Licence. Use, distribution and reproduction are unrestricted. Authors and original publication must be credited. 
removed permanently from aquatic ecosystems as dinitrogen $\left(\mathrm{N}_{2}\right)$ during the bacterial processes denitrification $\left(\mathrm{NO}_{3}{ }^{-} \rightarrow \mathrm{NO}_{2}{ }^{-} \rightarrow \mathrm{NO} \rightarrow \mathrm{N}_{2} \mathrm{O} \rightarrow \mathrm{N}_{2}\right.$; Zumft 1997) and anaerobic ammonium $\left(\mathrm{NH}_{4}^{+}\right)$oxidation (anammox: $\mathrm{NH}_{4}{ }^{+}+\mathrm{NO}_{2}{ }^{-} \rightarrow \mathrm{N}_{2 i}$ Mulder et al. 1995, van de Graaf et al. 1995). In shallow coastal areas, such as estuaries, the contribution of denitrification to total $\mathrm{N}_{2}$ production is usually more significant than that of anammox, which is more important in deeper areas (Risgaard-Petersen et al. 2004, Dalsgaard et al. 2005). This depth dependency mainly follows the availability of labile organic carbon (OC), which is usually higher in coastal and estuarine systems and thus favours fast-growing, heterotrophic denitrification bacteria over slow-growing, autotrophic anammox bacteria (Risgaard-Petersen et al. 2004, Engström et al. 2005).

Estuarine sediments are often efficient in removing riverine $\mathrm{NO}_{3}{ }^{-}$via denitrification (Seitzinger 1988, Nixon et al. 1996, Trimmer et al. 1998, Bonaglia et al. 2014) due to the abundant river discharge of the substrates $\mathrm{NO}_{3}{ }^{-}$and OC. At the same time, high $\mathrm{N}$ loading can increase the production of nitrous oxide $\left(\mathrm{N}_{2} \mathrm{O}\right)$, a potent greenhouse gas (Seitzinger \& Nixon 1985, Middelburg et al. 1995). However, various estuaries also show low removal rates relative to the load entering the system (Nielsen et al. 1995, Silvennoinen et al. 2007, Hietanen \& Kuparinen 2008, Jäntti et al. 2011, Deek et al. 2013), and estuarine $\mathrm{N}_{2} \mathrm{O}$ production in response to $\mathrm{N}$ loading can vary strongly over space and time (Middelburg et al. 1995).

Within the sediment, denitrification takes place at the oxic-anoxic interface (Christensen et al. 1989), where $\mathrm{NO}_{3}^{-}$or nitrite $\left(\mathrm{NO}_{2}^{-}\right)\left(\mathrm{NO}_{3}^{-}+\mathrm{NO}_{2}^{-}\right.$, in the following $\mathrm{NO}_{\mathrm{x}}^{-}$) from the water column or formed within the oxic surface sediment by nitrification $\left(\mathrm{NH}_{4}{ }^{+} \rightarrow \mathrm{NO}_{2}^{-} \rightarrow \mathrm{NO}_{3}^{-}\right.$; Prosser 1989) diffuses into anoxic layers. The application of measurement methods that are based on the diffusion of a tracer along vertical redox zones, such as the isotope pairing technique (IPT, Nielsen 1992), has led to a high number of denitrification measurements in fine-grained, cohesive, muddy sediments (e.g. Rysgaard et al. 1993, Dong et al. 2000, Hietanen \& Kuparinen 2008, Jäntti et al. 2011, Bonaglia et al. 2014). Measurements in sandy sediments are rare, although $\sim 50 \%$ of the inner continental shelf is covered by sand (Hall 2002). Sands can be highly permeable, which facilitates advective pore water flow through the sediment (Thibodeaux \& Boyle 1987, Huettel \& Gust 1992), increasing turnover rates and leading to, for example, low OC content (Boudreau et al. 2001). Advective pore water flow through permeable sands cre- ates complex vertical and horizontal redox zones and thereby complicates measurement methodology (Huettel et al. 2014). However, not all sandy sediments are permeable enough to enable pore water flow (Glud et al. 1996, Forster et al. 2003); in such non-permeable sands, the application of standard diffusive methods for denitrification measurements is possible.

The Baltic Sea in northern Europe is a semienclosed, brackish sea that receives substantial riverine inputs from a catchment area populated by $\sim 85$ million people and intensively used for agriculture and industry. Most rivers carry a significant load of nutrients and organic matter, leading to a clear dominance of eutrophic over oligotrophic estuaries. The few oligotrophic estuaries are mainly located in the Gulf of Bothnia, northern Baltic Sea (HELCOM 2014). Their trophic state reflects a reference state of the environment prior to major anthropogenic eutrophication, which in the Baltic Sea is the period before the 1950s (Andersen et al. 2004). For example, the average total N (TN) concentration of the Swedish Öre River, which discharges into one of the few oligotrophic estuaries in the Baltic Sea, was $\sim 25 \mu \mathrm{M}$ in 2015 (http://miljodata.slu.se/mvm/). This is within the TN range (19-58 $\mu \mathrm{M})$ given as the reference conditions for a pre-anthropogenic state for the Danish estuaries Odense, Randers and Roskilde Fjord (Andersen et al. 2004). However, even in the Öre Estuary, both the TN and $\mathrm{NO}_{\mathrm{x}}{ }^{-}$loads have increased significantly since the late 1960s (http://miljodata. slu.se/mvm/). For the period 1994-2006, the increased $\mathrm{N}$ load in the estuary has been explained by increased freshwater discharge, which in combination with the phosphorus (P) limitation of the system led to a decrease in primary production and a shift of the system from autotrophy towards heterotrophy (Wikner \& Andersson 2012). As global warming is predicted to increase precipitation in high latitudes (Dore 2005) and consequently also freshwater discharge and nutrient loading (Wikner \& Andersson 2012), the fate of riverine $\mathrm{NO}_{\mathrm{x}}^{-}$in oligotrophic estuaries becomes unclear. An analysis of inorganic nutrients in river, estuarine and open waters indicated that northern Baltic oligotrophic estuaries do not necessarily act as sinks for riverine nutrients (Humborg et al. 2003), contrary to the general assumptions regarding estuaries.

To date, only a few studies have addressed $\mathrm{N}$ turnover in oligotrophic estuaries, either globally (e.g. Seitzinger 1987, Eyre et al. 2011, Gongol \& Savage 2016) or within the Baltic Sea (Stockenberg \& Johnstone 1997, Bonaglia et al. 2017). We measured $\mathrm{N}_{2}$ 
and $\mathrm{N}_{2} \mathrm{O}$ production in sandy and muddy sediments of the Öre Estuary to estimate the estuarine $\mathrm{N}$ removal, to compare the $\mathrm{N}$ removal between sediment types, and to determine the efficiency of an oligotrophic estuary as a sink for riverine $\mathrm{NO}_{\mathrm{x}}{ }^{-}$under conditions of high and low river outflow.

\section{MATERIALS AND METHODS}

\section{Study area and sampling}

The Öre Estuary on the Swedish coast of the Quark Strait between the Bothnian Sea and Bothnian Bay, northern Baltic Sea (Fig. 1), is a semi-enclosed, nontidal brackish water body of $\sim 70 \mathrm{~km}^{2}$, with a total volume of $\sim 0.7 \mathrm{~km}^{3}$ and a mean depth of $10 \mathrm{~m}$ (SMHI 2003), fed by the Öre River. To the east it is bounded by a dense archipelago; to the south its surface waters are open to the Bothnian Sea, while its deeper waters are confined by a threshold at $30 \mathrm{~m}$ depth, creating a natural border (Brydsten 1992). Water circulation in the estuary is wind driven and in spring additionally fluvial driven (Brydsten \& Jansson 1989). Fluvial currents are strongest during the spring flood (April, May), which results from the snow melt and is a pulse event in the annual discharge regime (maximum river discharge: $500 \mathrm{~m}^{3} \mathrm{~s}^{-1}$, Malmgren \& Brydsten 1992). In the year of this study (2015), the first peak discharge was on 24-25 April (151 $\left.\mathrm{m}^{3} \mathrm{~s}^{-1}\right)$, followed by a second peak on 11-13 May $\left(186 \mathrm{~m}^{3} \mathrm{~s}^{-1}\right)$ (Fig. 2). The mean annual discharge is $36 \mathrm{~m}^{3} \mathrm{~s}^{-1}$ (2004-2014; http://vattenwebb.smhi.se/station/). The flood plume can extend several kilometres into the estuary and carries $70-80 \%$ of the annual river load of suspended matter (Brydsten \& Jansson 1989). In 2015, the load of $\mathrm{NO}_{\mathrm{x}}{ }^{-}$related to the spring flood (April, May) was 24 t, while the summer load (JuneAugust) at normal river discharge was only $1.8 \mathrm{t}$ in total. The average annual load of $\mathrm{NO}_{\mathrm{x}}{ }^{-}$is $\sim 54 \mathrm{t} \mathrm{yr}^{-1}$ (1967-2014, http://miljodata.slu.se/mvm/). Particle retention time is $<1 \mathrm{~d}$ in the plume but $\geq 1 \mathrm{yr}$ in the estuary, and particle transport to the open sea only takes place via repeated cycles of resuspensionredeposition events (Brydsten \& Jansson 1989). About $30 \%$ of the estuarine surface sediments are soft, consisting of $10 \%$ fine sand and $90 \%$ clay and silt (calculated from marine surface substrate data 1:100 000 () Geological Survey of Sweden, ESRI ArcGIS, ArcMap 10.3.1).

Samples for the determination of estuarine $\mathrm{N}_{2}$ production were collected on 20-24 April and 3-7

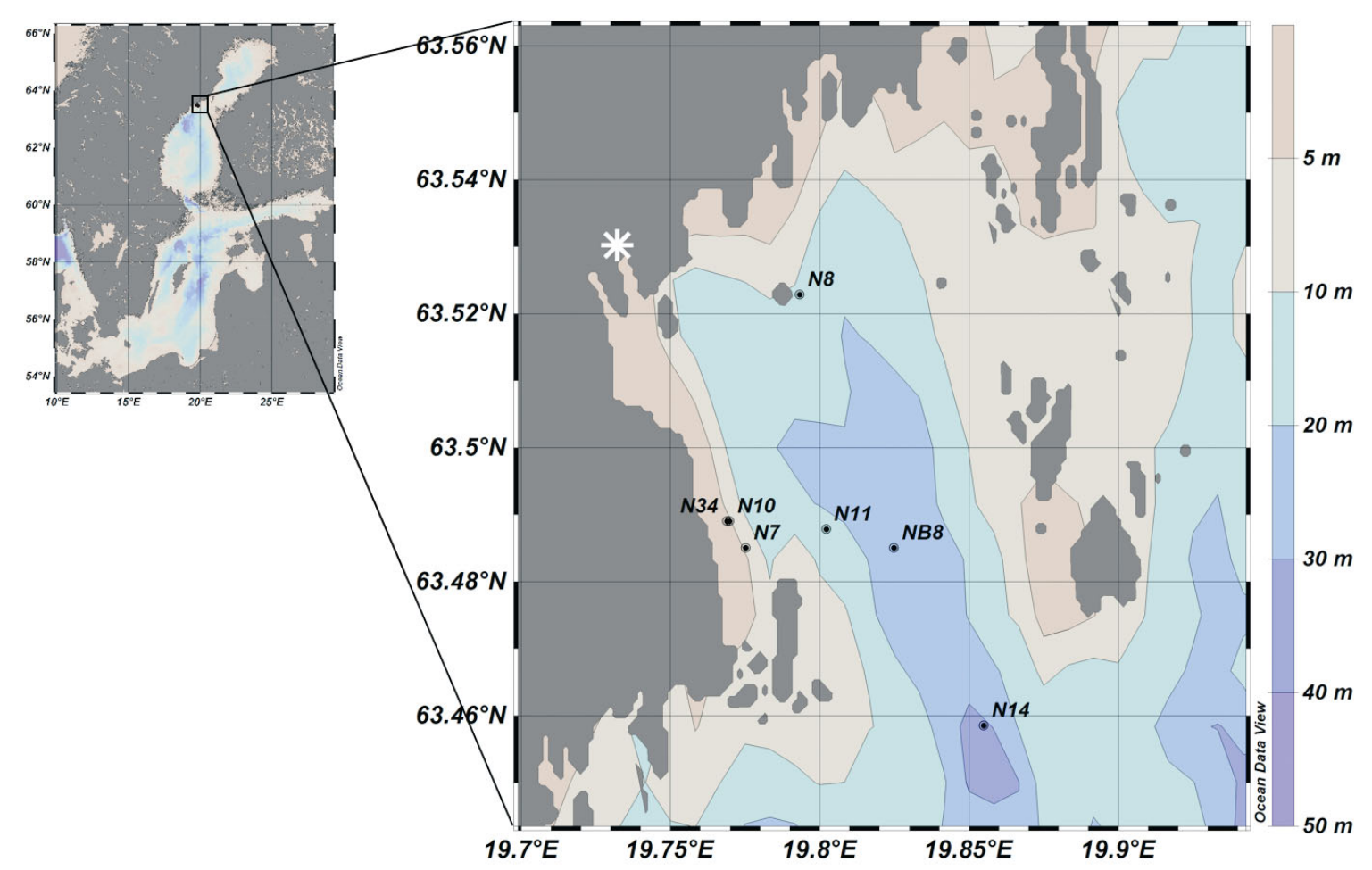

Fig. 1. The Öre Estuary on the Swedish coast of the Quark Strait, between the Bothnian Sea and Bothnian Bay, northern Baltic Sea, with the sampling sites shown. The Öre River mouth is indicated with an asterisk. Figure drawn using Ocean Data View (Schlitzer 2015) 


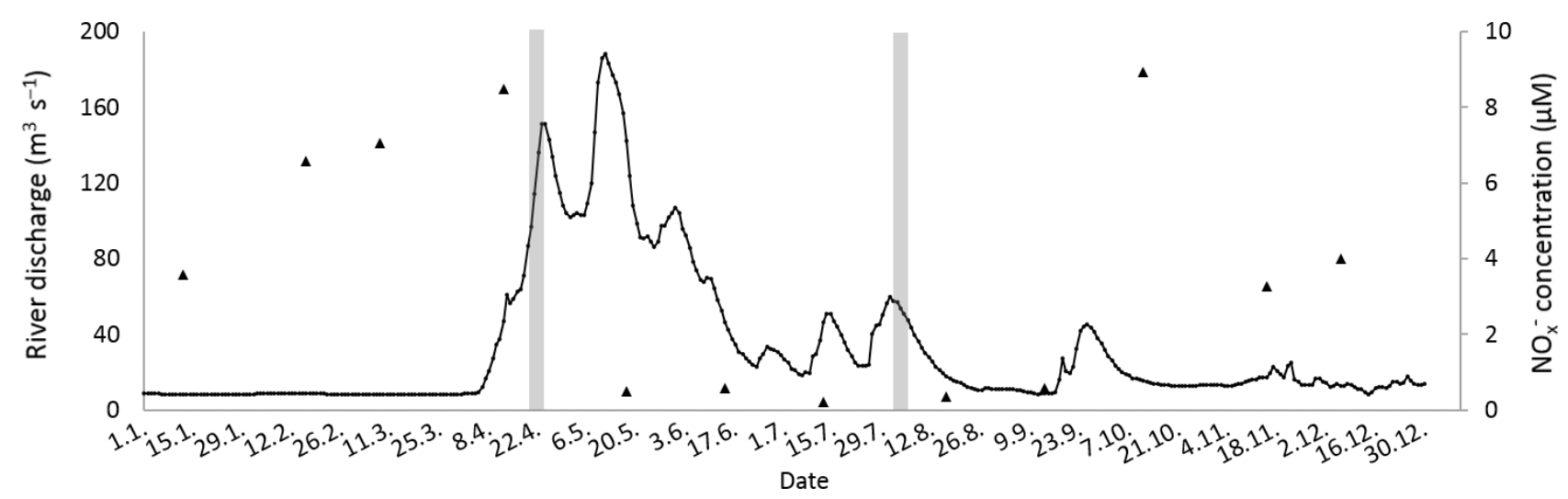

Fig. 2. Öre River discharge $\left(\mathrm{m}^{3} \mathrm{~s}^{-1}\right.$; line) and $\mathrm{NO}_{\mathrm{x}}{ }^{-}$(combined nitrate + nitrite) concentration $(\mu \mathrm{M}$; triangles) of river surface waters in 2015 (measured at station 'Torrböle 2', http://vattenwebb.smhi.se/station/, http://miljodata.slu.se/mvm/). Sampling periods in April and August are shaded. Dates are given as dd.mm

August 2015 (Table 1), representing periods of high and low river discharge, respectively, and corresponding material load into the system (Fig. 2). Samples were collected onboard RV 'Lotty' (Umeå Marine Sciences Centre) from muddy and sandy bottoms along a transect approximately following the Öre River plume towards the open sea (except site N8, located north of the transect, Fig. 1). Water column hydrographic parameters and photosynthetically active radiation (PAR) were measured with a CTD probe (April: SBE 19plus, August: SBE 19plus V2, Sea-Bird Scientific) equipped with a PAR sensor (QSP-2350, Biospherical Instruments). Bottom water dissolved $\mathrm{O}_{2}$ was measured with Winkler titration (April) and an $\mathrm{O}_{2}$ probe (August) (Seaguard CTD, Aanderaa). Water samples for the determination of particulate $\mathrm{OC}$ and $\mathrm{N}$ (POC, PON) and natural abundance of stable carbon isotopes $\left(\delta^{13} \mathrm{C}\right.$-POC) were taken with a Niskin bottle from surface, mid and bottom water layers at 8 (April) or 11 (August) stations along the transect as well as from the river. Sediment samples were collected with a Gemini twin corer (mud) (core $\varnothing 8 \mathrm{~cm}$, length $80 \mathrm{~cm}$ ) and a HAPS bottom corer (sand) (core $\varnothing 14 \mathrm{~cm}$, length $30 \mathrm{~cm}$; KC Denmark) with a vibrator unit attached (power $180 \mathrm{~W}$, frequency $3000 \mathrm{~Hz}$, vibration time 10-15 s). Bottom water $\mathrm{NO}_{\mathrm{x}}{ }^{-}$concentrations were measured from a sample withdrawn $\sim 5 \mathrm{~cm}$ above the sediment surface of 1 core, filtered $(0.2 \mu \mathrm{m})$ and frozen until analysis with a nutrient auto analyser (QuikChem FIA+ 8000 Series, detection limit: $0.143 \mu \mathrm{M}_{i}$ Lachat Instruments). Grain size distribution (sandy sites only) and organic content estimated as loss on ignition (LOI) were analysed from surface sediment slices (mud: $0-1 \mathrm{~cm}$; sand: $0-1,1-2,2-3 \mathrm{~cm}$ in April, $0-0.5$, $0.5-1.0,1.0-1.5 \mathrm{~cm}$ in August). Sand permeability
$\left(K_{m}\right)$ was measured from surface sediments (homogeneous top layer of $\sim 0-1 \mathrm{~cm}$ ), which were collected from several replicate cores and pooled to a final volume of $\sim 11$. Samples for denitrification rate measurements $\left(\mathrm{n}=12\right.$ site $\left.^{-1}\right), \mathrm{O}_{2}$ penetration depth $(\mathrm{OPD}, \mathrm{n}=$ 3 site $\left.^{-1}\right)$ and porosity $\left(\mathrm{n}=3\right.$ site $\left.^{-1}\right)$ were collected in acrylic cores $(\varnothing 2.3 \mathrm{~cm}$, length $20 \mathrm{~cm})$, which were pushed gently into the sediment so that $\sim 1 / 3$ (mud) or $\sim 1 / 2$ (sand) of each core was filled with sediment and the rest with overlying water. Cores were closed without headspace. All samples were stored dark and cold and transported to the laboratory within $2 \mathrm{~h}$ of sampling.

\section{Sediment parameters}

Porosity was calculated from the sediment content of intact cores $\left(20-40 \mathrm{~cm}^{3}\right)$ via weight loss in drying $\left(105^{\circ} \mathrm{C}\right.$, overnight) according to Burdige (2006). LOI (weight\%) was calculated from surface slices via weight loss of dried sediment during combustion $\left(550^{\circ} \mathrm{C}, 4 \mathrm{~h}\right)$. Sand sediments were classified according to Wentworth (1922) with the adjustment of subdividing the class 'sand' into the grain size classes $>1.0,>0.5,>0.25,>0.125$ and $>0.063 \mathrm{~mm}$ after wet sieving (test sieves DIN ISO 3310-1, Haver \& Boecker). Grain size dominances (\%) were analysed per depth interval, but due to vertical homogeneity, results were pooled to determine the average surface sediment class. $K_{m}\left(\mathrm{~m}^{2}\right)$ was measured with a permeameter cell (Humboldt) using the constant head method for laminar flow of water through granular soil according to manufacturer's instructions. Constant water flow through the sediment column $\left(700 \mathrm{~cm}^{3}\right)$ was ensured before first readings of the volumetric 


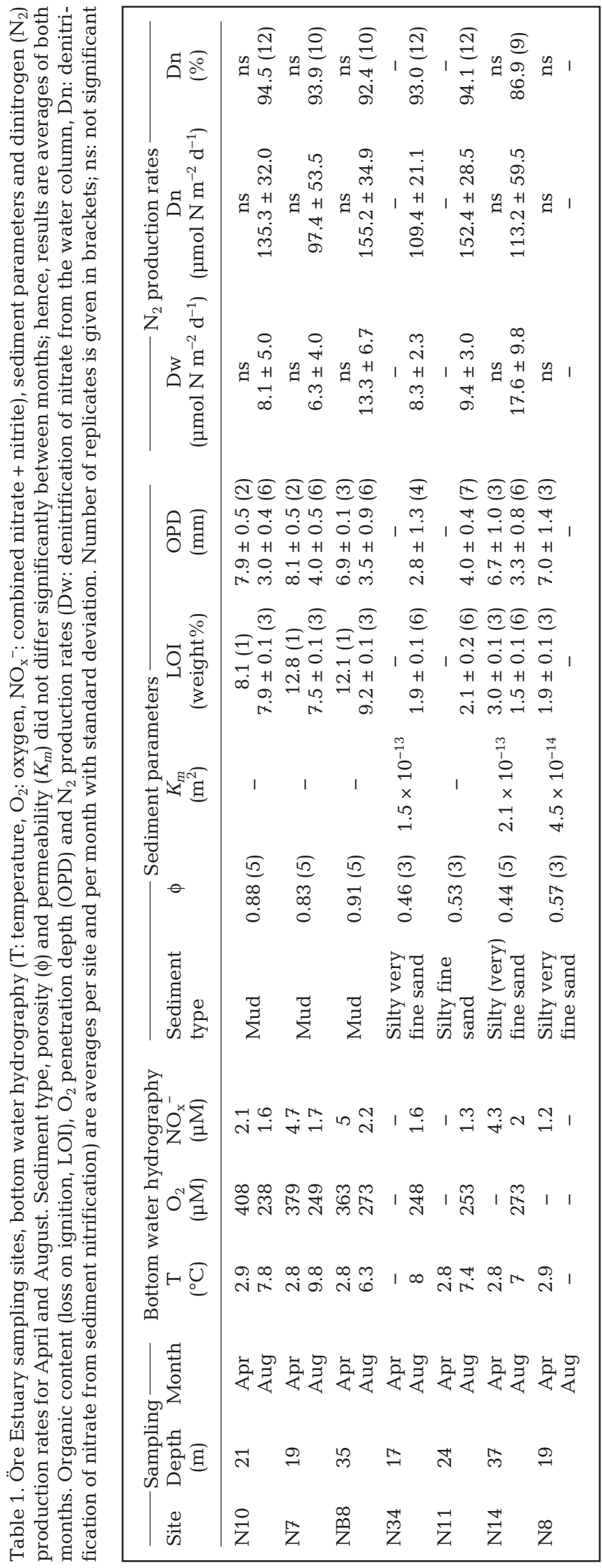

flow rate were taken. The influence of salt on water viscosity and density was negligible due to low salinity. Measurements were done at 3 hydraulic head heights with 3 replicate readings. Sieved sand of the size classes $0.5-1.0 \mathrm{~mm}$ (coarse), $0.25-0.5 \mathrm{~mm}$ (medium) and $0.125-0.25 \mathrm{~mm}$ (fine) was used as standard. The coefficient of permeability (hydraulic conductivity, $k$ ) was calculated with Eq. (1), derived from Darcy's Law:

$$
k=\frac{1 \cdot Q}{A \cdot h \cdot t}
$$

where $l=$ length of sediment column $(\mathrm{cm}), Q=$ outflow volume (ml), $A$ = sediment area exposed to flow $\left(\mathrm{cm}^{2}\right), h=$ hydraulic head $(\mathrm{cm}), t=$ time $(\mathrm{s}) . k$ was averaged for each height and sample, corrected for temperature effects on viscosity and converted to permeability $\left(K_{m}\right)$ (Eq. 2):

$$
K_{m}=\frac{k \cdot \mu}{\rho \cdot g}
$$

where $\mu=$ dynamic viscosity at bottom water temperature and salinity $(\mathrm{Pa} \cdot \mathrm{s}), \rho=$ density at bottom water temperature and salinity $\left(\mathrm{kg} \mathrm{m}^{-3}\right), g=$ gravitational acceleration $\left(9.81 \mathrm{~m} \mathrm{~s}^{-2}\right)$. At $K_{m} \geq 2.5 \times 10^{-12} \mathrm{~m}^{2}$, advective pore water flow can significantly affect sediment biogeochemistry, while at $K_{m}<2.5 \times 10^{-12} \mathrm{~m}^{2}$, such effects are negligible (Forster et al. 2003).

\section{Sediment oxygen concentration profiles}

Sediment $\mathrm{O}_{2}$ profiles were measured at in situ temperature within $2 \mathrm{~h}$ of sampling using Clark-type microelectrodes $(100 \mu \mathrm{m}$ tip, vertical resolution $250 \mu \mathrm{m}_{i}$ OX-100, Unisense) connected to a microsensor amplifier (4-Channel Multimeter, Unisense). For each site, electrodes were calibrated before profiling with a 2-point calibration at corresponding salinity and temperature $\left(100 \%\right.$ : $\mathrm{O}_{2}$ saturated site water, $0 \%$ : $2 \mathrm{~g}$ sodium ascorbate in $100 \mathrm{ml} 0.1 \mathrm{M}$ sodium hydroxide). Profiling was done either manually (April, 1 profile core $^{-1}$ ) or with an automated micromanipulator (August, 3 profiles core $^{-1}$ ), both without stirring applied. Subsequently, samples were incubated in the same way as the denitrification samples (see 'denitrification measurements'). Concentration profiles were measured again at the end of the incubation to examine whether the incubation conditions had changed the $\mathrm{O}_{2}$ profiles and thus the natural conditions. Sediment OPD was analysed from each profile with the sediment surface identified from a characteristic break in the profile curve, and averaged per site (Table 1). 


\section{Denitrification measurements}

$\mathrm{N}_{2}$ and $\mathrm{N}_{2} \mathrm{O}$ production rates were measured using the revised IPT (r-IPT; Risgaard-Petersen et al. 2003) that accounts for the potential contribution of the anammox process to total $\mathrm{N}_{2}$ production. Samples in acrylic cores were enriched with $\mathrm{K}^{15} \mathrm{NO}_{3}\left(98 \%{ }^{15} \mathrm{~N}\right.$, Cambridge Isotope Laboratories) in a concentration series to final concentrations of 30,60, 90 and $120 \mu \mathrm{M}$ in the overlying water ( $\mathrm{n}=3$ per concentration, Fn range: $86-99 \%$ in April, $94-99 \%$ in August), and incubated in the dark at in situ temperature under gentle mixing from magnetic stirring bars for $5 \mathrm{~h}$ (April) or $4 \mathrm{~h}$ (August). Incubations were terminated by mixing the sediment with the overlying water. After brief sediment settling, $12 \mathrm{ml}$ subsamples were placed into gas-tight glass vials (Exetainer, Labco Scientific) with $0.5 \mathrm{ml} \mathrm{ZnCl} 2(100 \% \mathrm{w} / \mathrm{v})$. The isotopic compositions of $\mathrm{N}_{2}$ and $\mathrm{N}_{2} \mathrm{O}$ were analysed with a continuous flow isotope ratio mass spectrometer (CFIRMS IsoPrime 100, Isoprime; standard gases: $\mathrm{N}_{2}>$ $99.999 \%$ purity, carbon dioxide $\left[\mathrm{CO}_{2}\right]$ as reference gas for $\mathrm{N}_{2} \mathrm{O}>99.995 \%$ purity; AGA) coupled to a preconcentrator system (TraceGas, Isoprime) and an automated liquid handler (GX-271, Gilson) at the Department of Environmental Sciences, University of Jyväskylä, Finland.

According to the r-IPT, a contribution of anammox to the measured $\mathrm{N}_{2}$ production is indicated in a positive correlation of the production of ${ }^{14} \mathrm{~N}-\mathrm{N}_{2}$ (calculated with the classical IPT, Nielsen 1992) with the added ${ }^{15} \mathrm{NO}_{3}{ }^{-}$concentrations. In such a case, the production of $\mathrm{N}_{2}$ has to be distinguished between anammox and denitrification, and calculations follow Risgaard-Petersen et al. (2003). If the production of ${ }^{14} \mathrm{~N}-\mathrm{N}_{2}$ does not show a positive correlation with the added ${ }^{15} \mathrm{NO}_{3}{ }^{-}$concentrations, denitrification is assumed to be the only process of $\mathrm{N}_{2}$ production (Risgaard-Petersen et al. 2003), and calculations follow Nielsen (1992). In both cases, the production of ${ }^{15} \mathrm{~N}$ $\mathrm{N}_{2}$ must show a linear dependency with the added ${ }^{15} \mathrm{NO}_{3}{ }^{-}$concentrations to fulfil the assumption of $\mathrm{NO}_{3}{ }^{-}$limitation of the incubated samples, which is a prerequisite of the valid application of both IPT and r-IPT. All dependencies were tested with a regression analysis (significance level $\mathrm{p}<0.05$ ).

Following this approach, no contribution of anammox to $\mathrm{N}_{2}$ production was found in any of our samples. Hence, $\mathrm{N}_{2}$ production rates from denitrification were determined according to the classical IPT (Nielsen 1992): denitrification of the added ${ }^{15} \mathrm{NO}_{3}{ }^{-}$ (termed D15) was calculated from the production rates of ${ }^{29} \mathrm{~N}_{2},{ }^{30} \mathrm{~N}_{2}$ and ${ }^{45} \mathrm{~N}_{2} \mathrm{O},{ }^{46} \mathrm{~N}_{2} \mathrm{O}$. Subsequently, denitrification of ${ }^{14} \mathrm{NO}_{3}{ }^{-}$(D14, the genuine $\mathrm{N}_{2}$ production) was calculated assuming random pairing of the isotopic species ${ }^{15} \mathrm{NO}_{3}{ }^{-}$and ${ }^{14} \mathrm{NO}_{3}{ }^{-}$and thus binomial distribution of isotopic $\mathrm{N}_{2}$ production. The denitrification rates of $\mathrm{NO}_{3}{ }^{-}$from the bottom water (Dw) and from sediment nitrification (Dn, coupled nitrification-denitrification) were calculated from D14 and the ratio of ${ }^{15} \mathrm{NO}_{3}{ }^{-}$to ${ }^{14} \mathrm{NO}_{3}{ }^{-}$in the water phase. The percentage of steady state denitrification of the added ${ }^{15} \mathrm{NO}_{3}{ }^{-}$, reached within the applied incubation time, was estimated according to Dalsgaard et al. (2000) using average measured OPD and a diffusion coefficient of $\mathrm{NO}_{3}{ }^{-}$in sediment $\left(D_{\mathrm{s}}\right)$, calculated from measured porosity and a diffusion coefficient of $\mathrm{NO}_{3}{ }^{-}$in water $\left(D_{0}\right)$ at bottom water temperature (Schulz 2005).

\section{Water column particulate matter, natural carbon isotope abundance and source attribution}

Water samples (250-2000 ml) were filtered over pre-combusted $\left(3 \mathrm{~h}, 450^{\circ} \mathrm{C}\right)$ glass fibre filters $(\mathrm{GF} / \mathrm{F}$ Whatman, nominal pore size $0.7 \mu \mathrm{m})$, which were immediately frozen $\left(-20^{\circ} \mathrm{C}\right)$. For the analysis of the elemental $(\mathrm{C}, \mathrm{N})$ and isotopic $\left({ }^{13} \mathrm{C}\right)$ composition of the suspended particulate matter, filters were dried $\left(60^{\circ} \mathrm{C}\right.$ overnight), packed into tin cups and measured with an isotopic ratio mass spectrometer (IRMS Delta V Advantage) connected to an elemental analyser (Flash 2000) via an open split interface (ConFlo IV, all Thermo Fisher Scientific; reference gases: $\mathrm{N}_{2}>99.999 \%$ purity, $\mathrm{CO}_{2}>99.995 \%$ purity, Linde, calibrated against standards from the International Atomic Energy Agency [IAEA] and National Bureau of Standards [NBS]: IAEA N1, N2, N3, C3, C6 and NBS 22). Measurements were calibrated against acetanilide and peptone (both Merck), and measurement precision was $\pm 0.2 \%$. The natural abundance $(\delta)$ of ${ }^{13} \mathrm{C}$-POC $(\%)$ was calculated according to Eq. (3):

$$
\left(\frac{R_{\text {sample }}}{R_{\text {standard }}}-1\right) \cdot 1000
$$

where $R$ = ratio of heavy to light isotope of sample $\left(R_{\text {sample }}\right)$ and standards $\left(R_{\text {standard }}\right)$.

To identify the source of particulate organic matter (POM) in the estuarine water column, we plotted the particulate $\mathrm{N}: \mathrm{C}$ ratio against $\delta^{13} \mathrm{C}-\mathrm{POC}$, following Goñi et al. (2003; see Fig. 7). End-member values of the POM source (terrestrial $\mathrm{C} 3$ plants $[\mathrm{N}: \mathrm{C}$ ratio of 0.02-0.05], marine phytoplankton, riverine and estuarine phytoplankton [N:C ratio of 0.13-0.17]) were based on published compositional ranges given by Goñi et al. (2003). We used a 2-component mixing 
model with the end-members 'terrestrially derived POM (EM terr $)^{\prime}$ and 'phytoplankton derived POM $\left(E M_{\text {phyto }}\right)^{\prime}$ for a first-order quantification of the relative contribution of each end-member to the total estuarine particulate matter, following Jilbert et al. (2017), as shown in Eqs. (4) \& (5):

$$
\begin{gathered}
\% \mathrm{POM}_{\text {phyt }}=\frac{\left(N / C_{\text {sample }}-N / C_{\text {EM-terr }}\right)}{\left(N / C_{\text {EM-phyt }}-N / C_{\text {EM-terr }}\right)} \times 100 \\
\% \mathrm{POM}_{\text {terr }}=100-\% \mathrm{POM}_{\text {phyt }}
\end{gathered}
$$

where $N / C_{\text {EM-terr }}=0.05$ and $N / C_{\text {EM-phyt }}=0.13$ are the outer limits of the compositional range of each endmember. The model assumes that only 2 sources of POM exist in the system and that their specific N:C ratios do not change over time.

\section{Statistical analysis}

Data were tested for normality (Shapiro-Wilk's test) and homogeneity of variances (Levene's test). A correlation analysis was done between all parameters, and a Bonferroni correction for multiple comparisons was applied. The effects of the factors 'season (April, August)' and 'sediment type (mud, sand)' on the response variables 'bottom water $\mathrm{NO}_{\mathrm{x}}{ }^{-1}$, 'porosity', 'LOI' and 'OPD' were tested with a repeated measures analysis of variance. This was done with the R soft- ware (version 3.1.1; R Core Team 2014) by fitting a linear mixed model (Eq. 6) that accounted for the interdependencies of the sites being measured twice (in April and August), using the lme4 package:

$$
\begin{aligned}
\text { Model_i: Response } \_\mathrm{i} \sim \operatorname{sediment} \cdot \boldsymbol{x} \_\mathrm{i}+\operatorname{season} \cdot \boldsymbol{x} \_\mathrm{i} \\
+\operatorname{sediment}: \operatorname{season} \cdot \boldsymbol{x} \_\mathrm{i}+\operatorname{random}(\operatorname{site})
\end{aligned}
$$

The response variable 'denitrification rate' was only analysed for an effect of the factor 'sediment type' with an analysis of variance (Eq. 7), as the seasonality could not be taken into account in these data (see 'Results'):

$$
\begin{aligned}
& \text { ANOVA_model: Denitrification_i } \sim \text { sediment } \cdot x_{-} \mathrm{i} \\
& \quad+\operatorname{site} \cdot x \_\mathrm{i}+\text { error }
\end{aligned}
$$

In all analyses, the significance level was $\mathrm{p}<0.05$.

\section{RESULTS}

The water column was stratified with a shallow, low-salinity surface layer both in April and August 2015. As a consequence, the surface river plume did not mix down to the sediments (Fig. 3). All sampled sediments were aphotic with bottom water PAR $<0.1 \%$ of surface PAR. Bottom water temperature, dissolved $\mathrm{O}_{2}$ and $\mathrm{NO}_{\mathrm{x}}{ }^{-}$concentrations differed between seasons, but the estuary did not experience hypoxia during the sampling periods (Table 1).

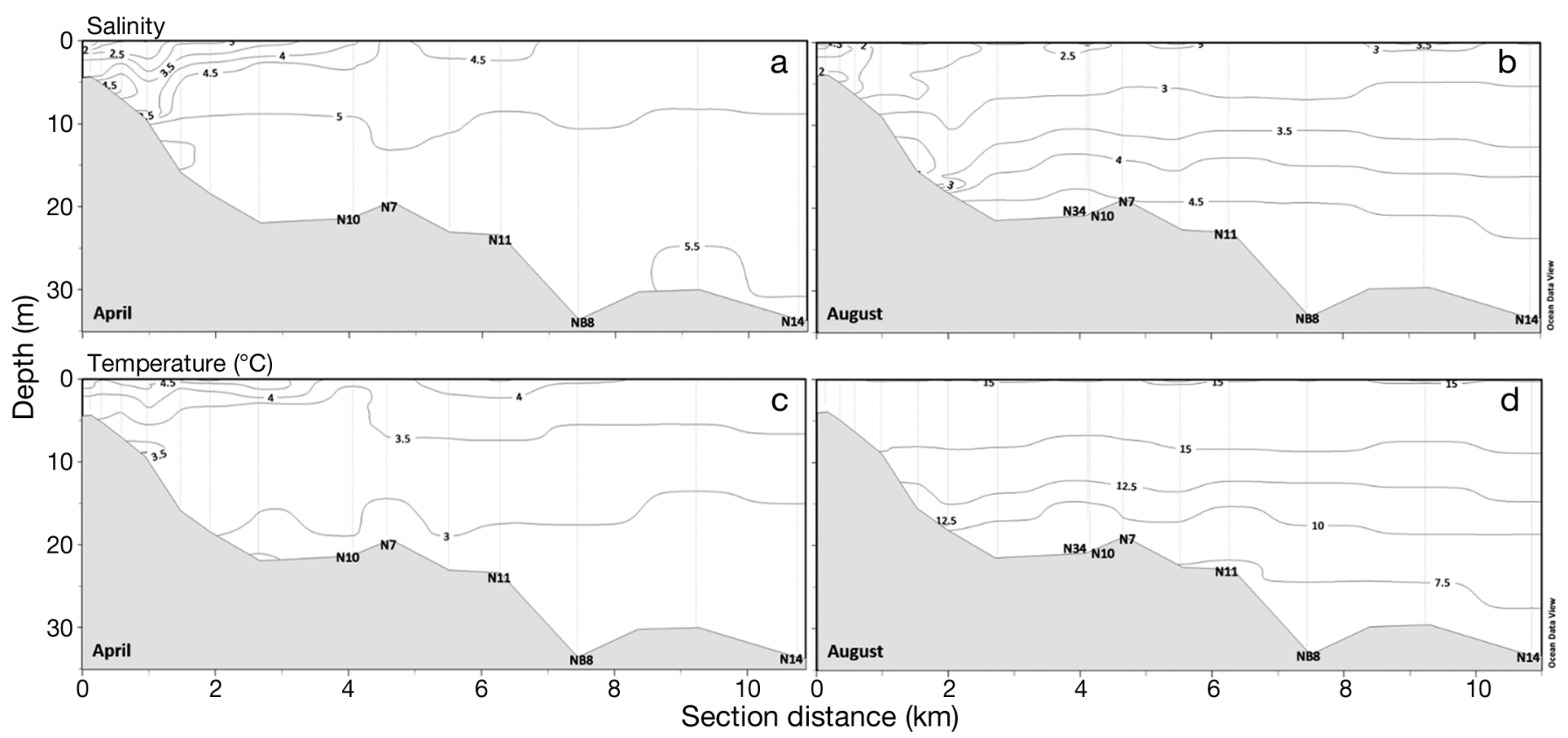

Fig. 3. $(a, b)$ Water column salinity and $(c, d)$ temperature in $(a, c)$ April and $(b, d)$ August along a transect from the Öre River mouth (distance 0 ) towards the estuary end, with the sampled sediment sites shown. Contour lines of salinity and temperature are extrapolated from 14 profiles along the transect (weighted-average gridding, quality limit 3) using Ocean Data View (Schlitzer 2015). Bottom topography estimated from bottom water depth 


\section{Sediment characteristics}

The sandy sediments were composed of poorly sorted very fine to fine sands with a large fraction of particles $<0.063 \mathrm{~mm}$. At sampling site N14, the only sandy site sampled in both seasons, the share of the smallest fractions $(<0.063 \mathrm{~mm},<0.125 \mathrm{~mm})$ was $60 \%$ higher in the top $1 \mathrm{~cm}$ in April (silty very fine sand) than in August (silty fine sand). All sandy sediments had a $K_{m}<2.5 \times 10^{-12} \mathrm{~m}^{2}$ and were thus classified as non-permeable, which excludes advective pore water flow as a transport mechanism of dissolved and particulate matter. The $K_{m}$ of N11 was not measured due to technical problems but was assumed to be nonpermeable, as the grain size distribution was very similar to that of the non-permeable N34. Porosity did not change significantly between seasons but differed between sediment types (Table 1). The organic content measured as LOI differed significantly both between seasons (April > August) and sediment types (muddy sediment > sandy sediment), independent of the site location on the plume transect (Table 1).

\section{Sediment oxygen concentration profiles}

Sediment $\mathrm{O}_{2}$ profiles were similar in muddy and sandy sediments, showing nearly parabolic curves (Fig. 4) indicative of diffusive mass transport (Revsbech et al. 1980a). Sediment OPD was not significantly different between sediment types but differed significantly between seasons (Table 1, Fig. 4). Average OPD in the sediment cores decreased during the incubations in April by $~ 9 \%(0.7 \pm 0.7$ [SD] mm over $5 \mathrm{~h}, \mathrm{n}=13)$ and in August by $\sim 16 \%(0.5 \pm 1.0 \mathrm{~mm}$ over $4 \mathrm{~h}, \mathrm{n}=15$ ).

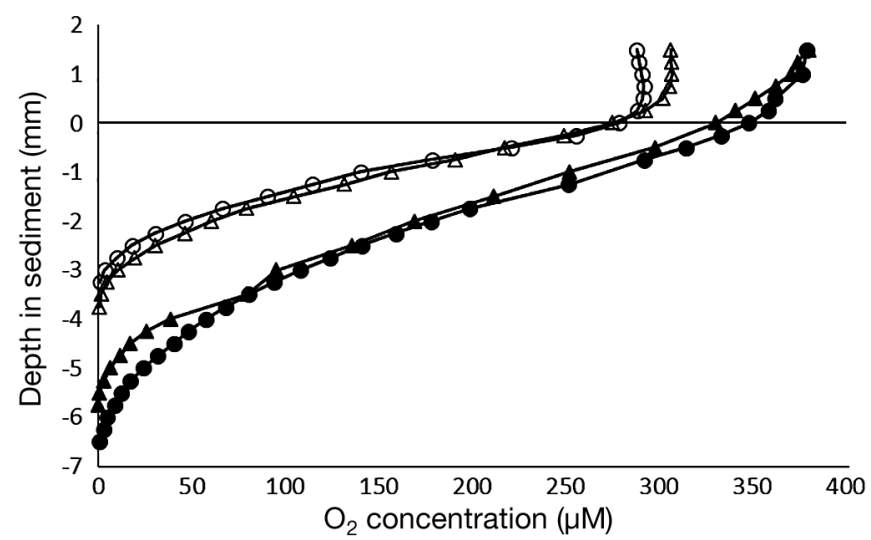

Fig. 4. Examples of oxygen $\left(\mathrm{O}_{2}\right)$ profiles in muddy (circles; sampling site NB8) and sandy (triangles; N14) sediments in April (black symbols) and August (white symbols). Zero line indicates the sediment surface
While profiling, the water within the cores was not stirred and consequently the thickness of the diffusive boundary layer could not be defined; the sediment surface was identified by a distinct break in the concentration profile. If OPD had decreased similarly during the $2 \mathrm{~h}$ time delay from sampling to measurement as seen during the incubations (which were, however, done under continuous stirring), then the in situ OPD could have been at least $280 \mu \mathrm{m}$ (April) to $250 \mu \mathrm{m}$ (August) deeper than reported here. This is within the resolution used for profiling $(250 \mu \mathrm{m})$; hence, the potential error should be negligible.

\section{Denitrification rates}

In April, ${ }^{15} \mathrm{~N}-\mathrm{N}_{2}$ production rates did not show a dependency with the added ${ }^{15} \mathrm{NO}_{3}{ }^{-}$concentrations (Fig. 5), indicating that either denitrification was not $\mathrm{NO}_{3}{ }^{-}$limited (Nielsen 1992, Risgaard-Petersen et al. 2003) or that the added tracer did not diffuse sufficiently to the denitrifying layer. With this prerequisite of IPT not fulfilled, the denitrification rates did not represent genuine $\mathrm{N}_{2}$ production. Based on the estimated $\mathrm{NO}_{3}{ }^{-}$diffusion time, all incubations reached $>65 \%$ steady state denitrification of ${ }^{15} \mathrm{NO}_{3}{ }^{-}$(N14 > $65 \%, \mathrm{~N} 7>75 \%, \mathrm{~N} 10>80 \%$, NB8 > 90\%) within the applied incubation time, except the incubation of site N8. According to the numerical model underlying this calculation (Dalsgaard et al. 2000), >65\% steady state denitrification of ${ }^{15} \mathrm{NO}_{3}{ }^{-}$would yield measurable $\mathrm{N}_{2}$ production (D14), while $\geq 80 \%$ steady state denitrification of ${ }^{15} \mathrm{NO}_{3}{ }^{-}$would yield reliable $\mathrm{N}_{2}$ production (D14). Consequently, all incubations (except N8) should have had sufficient tracer diffusing to the denitrification layer to yield measurable and even reliable (N10, NB8) $\mathrm{N}_{2}$ production.

In August, ${ }^{15} \mathrm{~N}-\mathrm{N}_{2}$ production rates showed a linear dependency with the added ${ }^{15} \mathrm{NO}_{3}{ }^{-}$concentrations (Fig. 5), fulfilling the requirements of IPT (Nielsen 1992, Risgaard-Petersen et al. 2003). The ${ }^{14} \mathrm{~N}-\mathrm{N}_{2}$ production rates did not correlate with the added ${ }^{15} \mathrm{NO}_{3}{ }^{-}$concentrations, indicating that anammox did not contribute to the measured $\mathrm{N}_{2}$ production, which was thus $100 \%$ from denitrification (Risgaard-Petersen et al. 2003). All incubations reached $\geq 80 \%$ steady state denitrification of ${ }^{15} \mathrm{NO}_{3}{ }^{-}$during the applied incubation time. The share of $\mathrm{N}_{2} \mathrm{O}$ produced during denitrification was $\leq 1 \%$ of total denitrification; hence, denitrification rates are given as $\Sigma \mathrm{N}_{2}+\mathrm{N}_{2} \mathrm{O}$. Denitrification rates differed significantly between sites but did not differ significantly between sediment types, with mean $\pm \mathrm{SD}$ rates of $137 \pm 45 \mu \mathrm{mol} \mathrm{N} \mathrm{m} \mathrm{N}^{-2} \mathrm{~d}^{-1}(\mathrm{n}=$ 

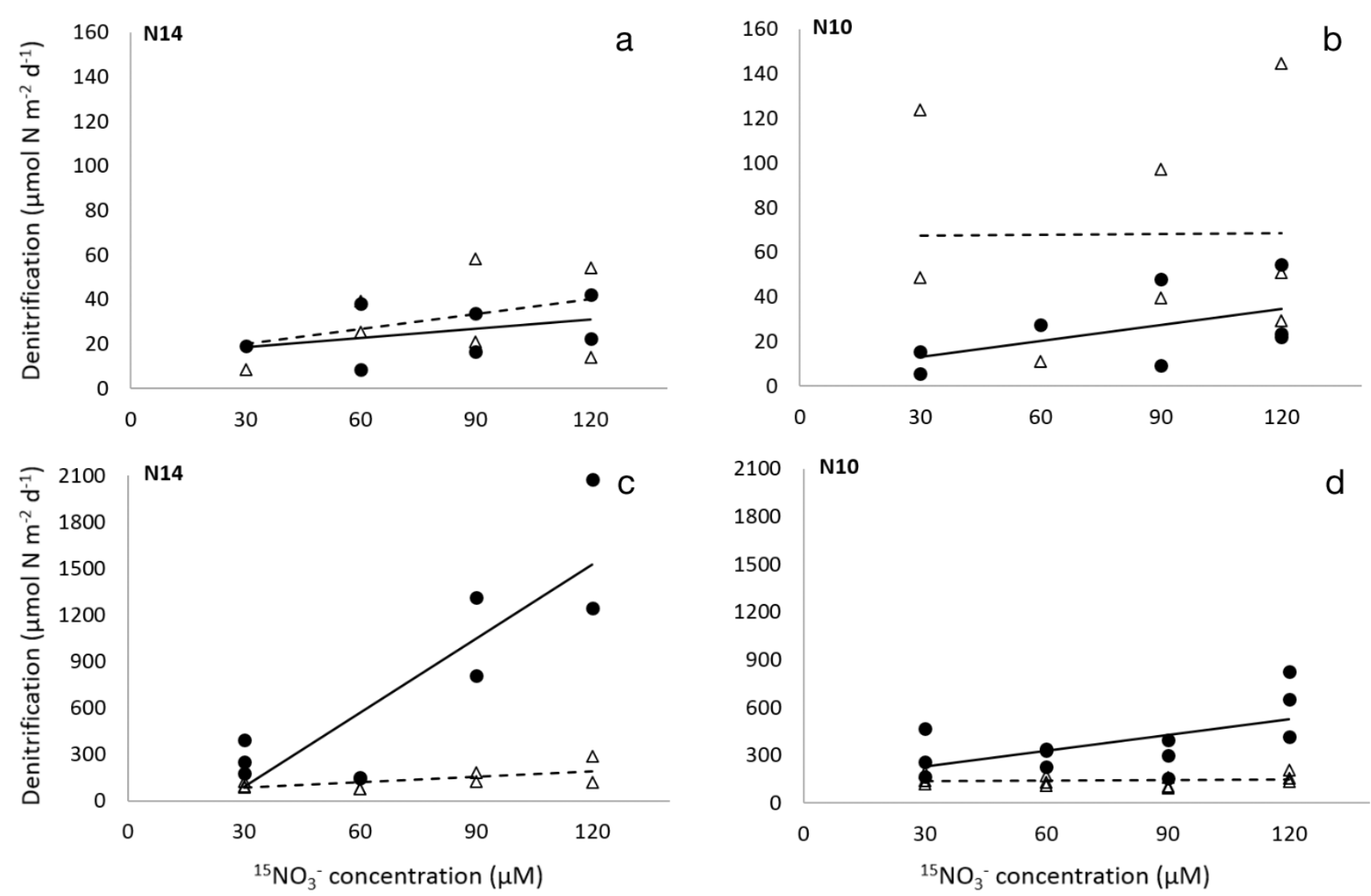

Fig. 5. Examples of production rates $\left(\mu \mathrm{mol} \mathrm{N} \mathrm{m}{ }^{-2} \mathrm{~d}^{-1}\right)$ of ${ }^{15} \mathrm{~N}-\mathrm{N}_{2}\left(\mathrm{D} 15\right.$; black circles, solid regression line) and ${ }^{14} \mathrm{~N}-\mathrm{N}_{2}(\mathrm{D} 14$; white triangles, dashed regression line) at different tracer concentrations ( $\mu \mathrm{M}^{15} \mathrm{NO}_{3}{ }^{-}$), shown for sites N14 (sandy) and N10 (muddy) in (a,b) April and (c,d) August. In April, D15 did not depend on tracer concentration and thus did not meet the requirements of the isotope pairing technique (IPT; Nielsen 1992) or the revised IPT (r-IPT; Risgaard-Petersen et al. 2003). Note the different $y$-axis scales in April and August

33) in sandy and $139 \pm 50 \mu \mathrm{mol} \mathrm{N} \mathrm{m}{ }^{-2} \mathrm{~d}^{-1}(\mathrm{n}=32)$ in muddy sediments. The main source of $\mathrm{NO}_{\mathrm{x}}^{-}$for denitrification in both sediment types was sediment nitrification (Dn $=87-95 \%$, Table 1). Dn correlated significantly negatively with particulate $\mathrm{C}: \mathrm{N}$ ratios of bottom waters, indicating higher Dn rates at higher $\mathrm{N}$ availability. Dw did not correlate with bottom water $\mathrm{NO}_{\mathrm{x}}{ }^{-}$, which could be due to the small share of Dw $(5-13 \%)$ or the low number of replicates.

\section{Water column particulate matter and natural carbon isotope abundance}

The concentrations of POM in the estuary did not follow the pattern of seasonal high and low river outflow and corresponding matter load (river POC/PON: 154/11 $\mu \mathrm{M}$ in April; 67/6 $\mu \mathrm{M}$ in August); concentrations in estuarine bottom waters were low in both months (POC/PON: 31/4 $\mu \mathrm{M}$ in Aprili $28 / 3 \mu \mathrm{M}$ in August, Table 2, Fig. 6). These averages exclude data from the near-bottom water layer $(0-30 \mathrm{~cm}$ from the sediment surface), which in August were enriched in POC $(\sim 200 \mu \mathrm{M})$ and PON $(\sim 20 \mu \mathrm{M}$, Table 2$)$, potentially indicating resuspension from the sediment. In both seasons, the river water showed typical terrestrial signals (C:N ratios elevated over 6.5 [Redfield ratio] and depleted $\delta^{13} \mathrm{C}$-POC values), while the estuarine waters showed phytoplankton signals (lower $\mathrm{C}: \mathrm{N}$ ratios and higher $\delta^{13} \mathrm{C}$-POC values, Table 2). This was confirmed by the results of the end-member mixing model, which estimated that the river water carried mostly terrestrially derived POM (71-56\%), whereas the estuarine waters contained mostly phytoplankton derived POM (60-95\%, Table 2, Fig. 7). Surprisingly, the riverine influenced estuarine surface waters had only a minor share of terrestrially derived POM $(30 \%$, Table 2, Fig. 7). The relative contribution of the 2 POM sources changed between April and August in the river (decrease in terrestrial signal) and the bottom waters (increase in terrestrial signal, Table 2). However, the latter is more likely the 
Table 2. Concentrations of riverine and estuarine (E) water column particulate organic carbon and nitrogen (POC, PON), particulate $\mathrm{C}: \mathrm{N}$ ratio, natural abundance of $\mathrm{C}$ isotope $\left(\delta^{13} \mathrm{C}-\mathrm{POC}\right)$ and origin of particulate organic matter (POM) from the mixed model (Eqs. 4 \& 5) for April and August. Values are averages for each water layer, with standard deviation and number of replicates (n)

\begin{tabular}{|c|c|c|c|c|c|c|c|c|c|}
\hline \multirow[t]{2}{*}{ Water source } & \multicolumn{5}{|c|}{$\longrightarrow$ Water column POM } & \multicolumn{4}{|c|}{ - Origin of POM } \\
\hline & Month & $\begin{array}{l}\text { POC } \\
(\mu \mathrm{M})\end{array}$ & $\begin{array}{l}\text { PON } \\
(\mu \mathrm{M})\end{array}$ & $\mathrm{C}: \mathrm{N}$ & $\mathrm{n}$ & $\begin{array}{c}\delta^{13} \mathrm{C}-\mathrm{POC} \\
(\%)\end{array}$ & $\begin{array}{c}\text { Terrestrial } \\
(\%)\end{array}$ & $\begin{array}{c}\text { Phytoplankton } \\
(\%)\end{array}$ & $\mathrm{n}$ \\
\hline \multirow[t]{2}{*}{ Öre River } & Apr & 153.6 & 11.2 & 13.7 & 1 & -29.1 & 71 & 29 & 1 \\
\hline & Aug & 67.2 & 5.7 & 11.7 & 1 & -30.2 & 56 & 44 & 1 \\
\hline \multirow[t]{2}{*}{ Surface layer (E) } & Apr & $42.6 \pm 12.0$ & $4.6 \pm 1.2$ & $9.3 \pm 0.8$ & 12 & $-26.1 \pm 1.6$ & 29 & 71 & 9 \\
\hline & Aug & $36.5 \pm 8.7$ & $4.0 \pm 0.7$ & $9.1 \pm 1.6$ & 16 & $-26.9 \pm 1.0$ & 23 & 77 & 16 \\
\hline \multirow[t]{2}{*}{ Mid layer (E) } & Apr & $37.8 \pm 8.2$ & $4.4 \pm 0.8$ & $8.5 \pm 0.5$ & 12 & $-25.2 \pm 1.0$ & 15 & 85 & 10 \\
\hline & Aug & $27.5 \pm 6.3$ & $3.2 \pm 0.7$ & $8.5 \pm 0.8$ & 16 & $-25.8 \pm 1.7$ & 15 & 85 & 16 \\
\hline \multirow[t]{2}{*}{ Bottom layer (E) } & Apr & $30.7 \pm 8.4$ & $4.0 \pm 1.2$ & $7.8 \pm 0.5$ & 11 & $-25.0 \pm 1.2$ & 5 & 95 & 8 \\
\hline & Aug & $28.2 \pm 1.6$ & $2.9 \pm 1.6$ & $9.6 \pm 1.3$ & 17 & $-25.9 \pm 1.1$ & 30 & 70 & 17 \\
\hline Near bottom & Apr & $47.5 \pm 14.4$ & $4.7 \pm 1.4$ & $10.2 \pm 0.7$ & 4 & $-25.7 \pm 0.8$ & 40 & 60 & 4 \\
\hline layer (E) & Aug & $198.3 \pm 90.8$ & $19.4 \pm 9.1$ & $10.3 \pm 0.4$ & 6 & $-26.1 \pm 0.4$ & 40 & 60 & 6 \\
\hline
\end{tabular}

result of POM degradation than an actual change in the POM source as the increased $\mathrm{C}: \mathrm{N}$ ratios at constant $\delta^{13} \mathrm{C}-\mathrm{POC}$ values indicate; such is not taken into account in the mixing model, which assumes constant $\mathrm{C}: \mathrm{N}$ ratios.

\section{DISCUSSION}

\section{Estuarine sediment characteristics and oxygen}

The sandy and muddy sediments of the Öre Estuary clearly had porosity and organic contents charac- teristic of each sediment type (Jahnke 2004). The sandy sediments contained a large amount of fine material, which shifted the main grain size to the fine end of the sand class (Wentworth 1922). Fine material such as silt or organic particles can accumulate in the open pore space of sand when water flow is not strong enough to remove it. Such accumulation of fine material reduces the permeability of the sediment drastically (Huettel et al. 1996, Forster et al. 2003) and can ultimately exclude advective pore water flow, leaving diffusion and potentially bioirrigation as the main transport mechanisms of matter into the sediment. Sandy sediments in the Öre

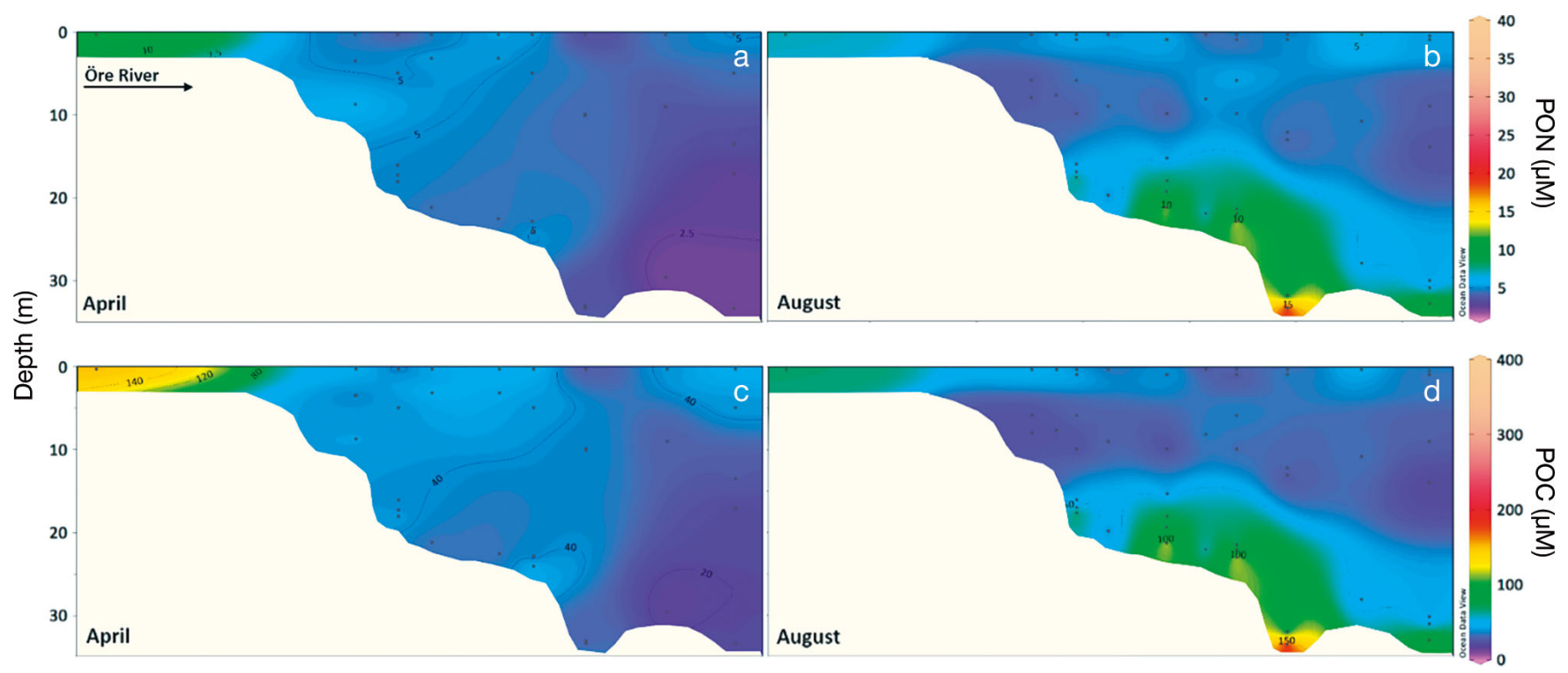

Fig. 6. Water column $(\mathrm{a}, \mathrm{b})$ particulate organic nitrogen $(\mathrm{PON})$ and $(\mathrm{c}, \mathrm{d})$ particulate organic carbon $(\mathrm{POC})$ concentrations $(\mu \mathrm{M})$ along a transect through the estuary, including the Öre River, for $(a, c)$ April and $(b, d)$ August. Data are extrapolated from 9 (April) and 11 (August) profiles (weighted-average gridding, quality limit 3, non-linear colour scale) using Ocean Data View (Schlitzer 2015). Bottom topography is estimated from bottom water depth 


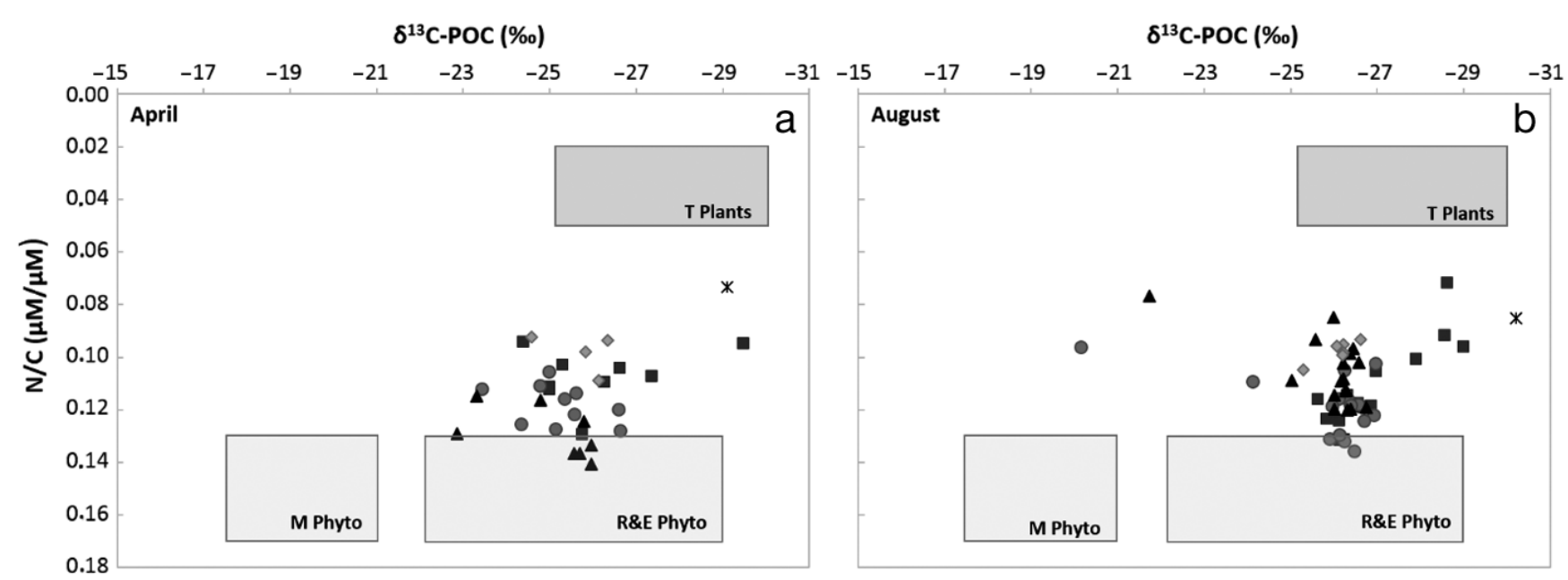

Fig. 7. Source attribution of particulate organic matter based on nitrogen:carbon (N:C) ratios plotted against natural abundances of $\mathrm{C}$ isotope $\left(\delta^{13} \mathrm{C}\right.$-POC) for (a) April and (b) August. The illustrated compositional ranges of 'T Plants' (terrestrial C3 vascular plant vegetation), 'M Phyto' (marine phytoplankton) and 'R\&E Phyto' (riverine and estuarine phytoplankton) are adapted from Goñi et al. (2003) and references therein. Asterisk: river water; squares: surface water; circles: mid-water; triangles: bottom water; diamonds: near-bottom water

Estuary are prone to clogging of pore space due to the silt- and clay-dominated riverine particle load (Forsgren \& Jansson 1993) and the long particle retention time within the estuary $(>1 \mathrm{yr}$; Brydsten \& Jansson 1989). The large amount of suspended fine particles that enters the estuary mainly during the spring flood (Brydsten \& Jansson 1989) was evident in the $60 \%$ higher proportion of fine material at N14 in April than in August. Not surprisingly, all studied estuarine sandy sediments were non-permeable and can thus be called cohesive sands.

Sandy sediments commonly have low organic content, usually considered a result of fast biogeochemical turnover due to advective pore water flow (Boudreau et al. 2001, Huettel et al. 2014). As the studied cohesive sands did not feature advective pore water flow, their low organic content $(\leq 3 \%)$ might be explained by sorption of organic matter to minerals. The degree of sorption depends on the available mineral surface area, which is smaller in sandy than in muddy sediments and consequently can lead to a smaller amount of sorbed matter (Mayer 1994a,b, Hedges \& Keil 1995, 1999).

The cohesive character of the sandy sediments could also be seen in the diffusive $\mathrm{O}_{2}$ concentration profiles, which were nearly identical to those of the cohesive muddy sediments. Hence, $\mathrm{O}_{2}$ penetrated both sediment types mainly by molecular diffusion. A contribution of faunal bio-irrigation to the sedimentary $\mathrm{O}_{2}$ transport was not quantified in this study; however, only a few $\mathrm{O}_{2}$ concentration profiles (April: $7 \%$, August: $3 \%$ ) showed signs of bio-irrigation.
The estuarine OPD changed significantly between seasons, which is typical in coastal sediments (Rasmussen \& Jørgensen 1992, Glud et al. 2003) and is related to temperature, organic matter availability and consequently $\mathrm{O}_{2}$ consumption. The OPD and its seasonal change was the same in both sediment types, in spite of different organic contents. The high organic content in the muddy sediments did not result in a shallower OPD than in the sandy sediments, as the quantity of organic matter does not necessarily reflect its quality in terms of lability of the OC compounds (Trimmer et al. 1998). Generally, autochthonous material is considered to be easier to mineralize than allochthonous material, which contains higher percentages of refractory compounds such as lignin or cellulose (Fenchel et al. 2012). However, unsorbed, autochthonous and thus labile $\mathrm{OC}$ is only a minor share of the total OC that is available for microbes (Nedwell 1987). If the high organic content in the muddy sediments consisted mostly of refractory and sorbed $\mathrm{OC}$, microbial activity in both sediments might have been limited by the amount of labile OC, resulting in similar $\mathrm{O}_{2}$ consumption and thus OPD.

In both seasons, the OPD in the sediments of the Öre Estuary reached deeper than in more eutrophic estuarine sediments of both the southern (e.g. Aarhus Bay, Danish coast, Rasmussen \& Jørgensen 1992, Glud et al. 2003) and the northern Baltic Sea (April: Storfjärden, Finnish coast, Gulf of Finland, Hietanen \& Kuparinen 2008; August: Himmerfjärden, Swedish coast, northern Baltic Proper, Bonaglia et al. 2014). These systems likely contain more organic matter 
and labile OC than the oligotrophic Öre Estuary, which has a catchment area of mainly coniferous forests and mires (Wikner \& Andersson 2012) and an annual primary production based on a single nutrient pulse during the spring flood. Moreover, the Öre Estuary does not suffer from the eutrophicationrelated hypoxia documented at the Storfjärden and Himmerfjärden sites (Hietanen \& Kuparinen 2008, Jäntti et al. 2011, Bonaglia et al. 2014). Consequently, the deep OPD in the Öre sediments is the result of high $\mathrm{O}_{2}$ supply at organic matter limited $\mathrm{O}_{2}$ consumption.

The thickness of OPD affects the source of $\mathrm{NO}_{\mathrm{x}}{ }^{-}$for denitrification (Dn, Dw) with a thick oxic sediment layer favouring Dn over Dw (Rysgaard et al. 1994). During our incubations, OPD decreased on average in all sediment cores despite continuous stirring of the overlying water, indicating that the $\mathrm{O}_{2}$ consumption rate in the sediment was faster than the $\mathrm{O}_{2}$ supply rate. A consequential decrease in the Dn:Dw ratio was probably negligible in our incubations, as the share of Dw was very low (5-13\%) in all samples. A $20 \%$ decrease in water column $\mathrm{O}_{2}$ concentration during closed incubations is commonly accepted as 'unchanged conditions' (Dalsgaard et al. 2000). The $\mathrm{O}_{2}$ concentration in the overlying waters of all our incubations decreased $<20 \%$, demonstrating that stable conditions above the sediment surface do not necessarily imply unchanged conditions within the sediment.

\section{Denitrification in an oligotrophic estuary}

Denitrification rates were measured in early spring and late summer to investigate rate differences with regard to the changing material load to the system (high and low river outflow). However, denitrification measurements in spring did not meet the method assumptions. All but one incubation had sufficient $\mathrm{NO}_{3}{ }^{-}$ tracer at the denitrification layer to theoretically yield measurable $\mathrm{N}_{2}$ production; thus, denitrification activity must have been limited by another factor. The time of sampling at the beginning of the annual main input of organic matter and nutrients suggests that the estuarine sediment system was still limited by labile OC, which serves as an energy source in heterotrophic denitrification (Hietanen \& Kuparinen 2008).

In the Öre Estuary, the riverine dissolved matter was not considered a significant source of labile OC for benthic processes, as it was likely confined to the surface waters based on its sources (riverine input, phytoplankton release) and separated from the sediments by water column stratification. The particulate matter in the estuarine bottom waters was estimated to be mainly derived from riverine and estuarine phytoplankton ( 95\%, Table 2), which represents a source of labile OC. However, fresh organic matter as such is not accessible for denitrifying bacteria, and a degradation to suitable carbon compounds (Hietanen \& Kuparinen 2008) had not yet happened as indicated by the low C:N ratio (7.8, Table 2). Availability of labile $\mathrm{OC}$ was also found to limit denitrification activity in OC-poor sediment layers affected by $\mathrm{NO}_{3}{ }^{-}$ rich groundwater discharge in an Atlantic estuary (Great South Bay, Slater \& Capone 1987). There, denitrification rates increased strongly after addition of labile OC (glucose). In conclusion, we suggest that denitrification during sampling in April was limited by the low availability of labile OC in sediments.

The same was concluded for another coastal site in the northern Baltic Sea with limited denitrification activity in spring (Hanko archipelago, Gulf of Finland, Jäntti et al. 2011). In contrast, Bonaglia et al. (2014) measured low but significant denitrification rates in May in the northern Baltic Himmerfjärden. Labile OC may not have limited denitrification in this eutrophic estuary, as autochthonous production in Himmerfjärden is supported by the continuous discharge of inorganic nutrients from the local sewage treatment plant.

Denitrification rates from aphotic depths of both the coastal and open Baltic Sea are generally much lower in spring than in late summer or early autumn (Tuominen et al. 1998, Hietanen \& Kuparinen 2008, Jäntti et al. 2011, Bonaglia et al. 2014). This is in contrast to shallow areas, where sediment denitrification rates are highest in spring at times of high $\mathrm{NO}_{\mathrm{x}}{ }^{-}$concentrations (Jørgensen \& Sørensen 1985, Seitzinger 1987, Nielsen et al. 1995, Jensen et al. 1996). Shallow areas exhibit a tight benthic-pelagic coupling (Middelburg \& Soetaert 2004), and surface waters rich in $\mathrm{NO}_{\mathrm{x}}^{-}$and organic matter, such as from a riverine spring flood, are in close contact with the sediment, where denitrification consequently follows the spring supply of substrate. In contrast, sediments in stratified waters are separated from surface waters, and the supply of organic matter to the sediment via sedimentation through the water column is delayed. Denitrification in such sediments can be temporally uncoupled from riverine peak discharges or bloom events.

Denitrification rates measured in August were in the same range in muddy and sandy sediments. This was probably due to similar bottom water temperature, mass transport mechanism and oxic sediment volume. In contrast, the organic content differed sig- 
nificantly between the sediment types. Similar to the sediment $\mathrm{O}_{2}$ dynamics, the same denitrification rates at different organic contents imply that not all of the organic matter in the sediment could be utilized by the denitrifying bacteria and that not only organic matter quantity but also quality needs to be considered (Hietanen \& Kuparinen 2008, Eyre et al. 2013, Bonaglia et al. 2017). This was also indicated by the lack of correlation of LOI with total denitrification, Dn or Dw.

We did not find any indication of anammox, which agrees with studies showing that its contribution to total $\mathrm{N}_{2}$ production is often less important in shallow estuarine than in deep open sea sediments (Dalsgaard et al. 2005). In estuaries, heterotrophic denitrification is often favoured over autotrophic anammox due to the usually high availability of labile organic matter (Risgaard-Petersen et al. 2004, Engström et al. 2005). Thus, in theory, the sediments of the oligotrophic Öre Estuary could have supported anammox, as seen in oligotrophic sediments of the coastal Bothnian Bay (Bonaglia et al. 2017). However, the occurrence of anammox often does not seem to follow a concise pattern. For instance, significant $\mathrm{N}_{2}$ production from anammox was present in the accumulation sediments of Storfjärden (Finnish coast, Gulf of Finland) in August 2003 (Hietanen \& Kuparinen 2008) but not in August 2008 or 2009 (Jäntti et al. 2011). This might also explain the contrasting results of observing (Bonaglia et al. 2017) and not observing anammox (this study) in 2 oligotrophic coastal sediments of the northern Baltic Sea.

Few denitrification measurements have been done in aphotic estuarine sediments of the Baltic Sea, and measurements from the northern parts (northern Baltic Proper to Bothnian Bay) are even scarcer (Table 3). Our measured summer denitrification rates are quite low compared with these (Table 3). Even lower rates from the central Öre Estuary were estimated by Stockenberg \& Johnstone (1997) using the acetylene blockage technique. However, as this method potentially underestimates denitrification (Seitzinger et al. 1993), the rates are not directly comparable. Similar low summer rates have been measured at a coastal transportation site with sandy mud sediments in the western Gulf of Finland (Jäntti et al. 2011) and in sediments of the open Baltic Sea (Tuominen et al. 1998, Deutsch et al. 2010, Bonaglia et al. 2017) (Table 3). Likely reasons for low denitrification rates in these locations were a low availability of labile OC (Tuominen et al. 1998, Deutsch et al. 2010, Jäntti et al. 2011, Bonaglia et al. 2017) and limited Dn due to low availability of $\mathrm{NH}_{4}{ }^{+}$for nitrifica- tion (Jäntti et al. 2011). Both reasons probably also apply to the oligotrophic Öre Estuary. The supply and availability of labile and N-rich organic matter decreases from south to north in the Baltic Sea together with the change in vegetation from farmland to forest and the decrease of anthropogenic influence in the catchment area (Stepanauskas et al. 2002); low availability of N-rich organic matter in the bottom waters of the Öre Estuary was evident in an elevated particulate C:N ratio of 9.6.

Few denitrification measurements have been made in oligotrophic estuaries and coastal sediments outside the Baltic Sea (Seitzinger 1987, Rysgaard et al. 2004, Eyre et al. 2011, Gongol \& Savage 2016), most of which are not fully comparable with those in our study due to their shallow water depths $(\sim 2-8 \mathrm{~m})$, enabling light penetration to the sediment surface and hence potential benthic primary production that can affect denitrification and anammox rates (Risgaard-Petersen et al. 2005). Only the sediments on the east coast of Greenland (Rysgaard et al. 2004) were aphotic and thus comparable with this study. The arctic denitrification rates $\left(\sim 50-110 \mu \mathrm{mol} \mathrm{N} \mathrm{m}{ }^{-2}\right.$ $\mathrm{d}^{-1}$ in August) were slightly lower than the rates in the Öre Estuary, likely due to the much lower temperatures $\left(-1.7\right.$ to $\left.-1.3^{\circ} \mathrm{C}\right)$.

$\mathrm{N}_{2} \mathrm{O}$ production as an intermediate product from denitrification was negligible in the Öre Estuary as also seen in other oligotrophic sediments (Seitzinger 1987, Gongol \& Savage 2016). This was to be expected, as significant $\mathrm{N}_{2} \mathrm{O}$ release during denitrification has mainly been observed under high organic matter loading (Seitzinger \& Nixon 1985, Middelburg et al. 1995), which does not apply to oligotrophic systems.

\section{Does the oligotrophic Öre Estuary function as a nitrogen sink?}

The general statement that estuaries are highly efficient in removing riverine $\mathrm{N}$ load via denitrification (Seitzinger 1988) has been challenged over the years by reports from some estuaries (e.g. Nielsen et al. 1995, Hietanen \& Kuparinen 2008, Deek et al. 2013), and in particular, some northern Baltic oligotrophic estuaries do not necessarily act as sinks for riverine nutrients (Humborg et al. 2003). The amount of $\mathrm{N}$ that is permanently removed from the river load is also a function of the local water residence time (Nielsen et al. 1995, Nixon et al. 1996, Holmes et al. 2000, Humborg et al. 2003, Silvennoinen et al. 2007, Finlay et al. 2013). A long residence time increases 


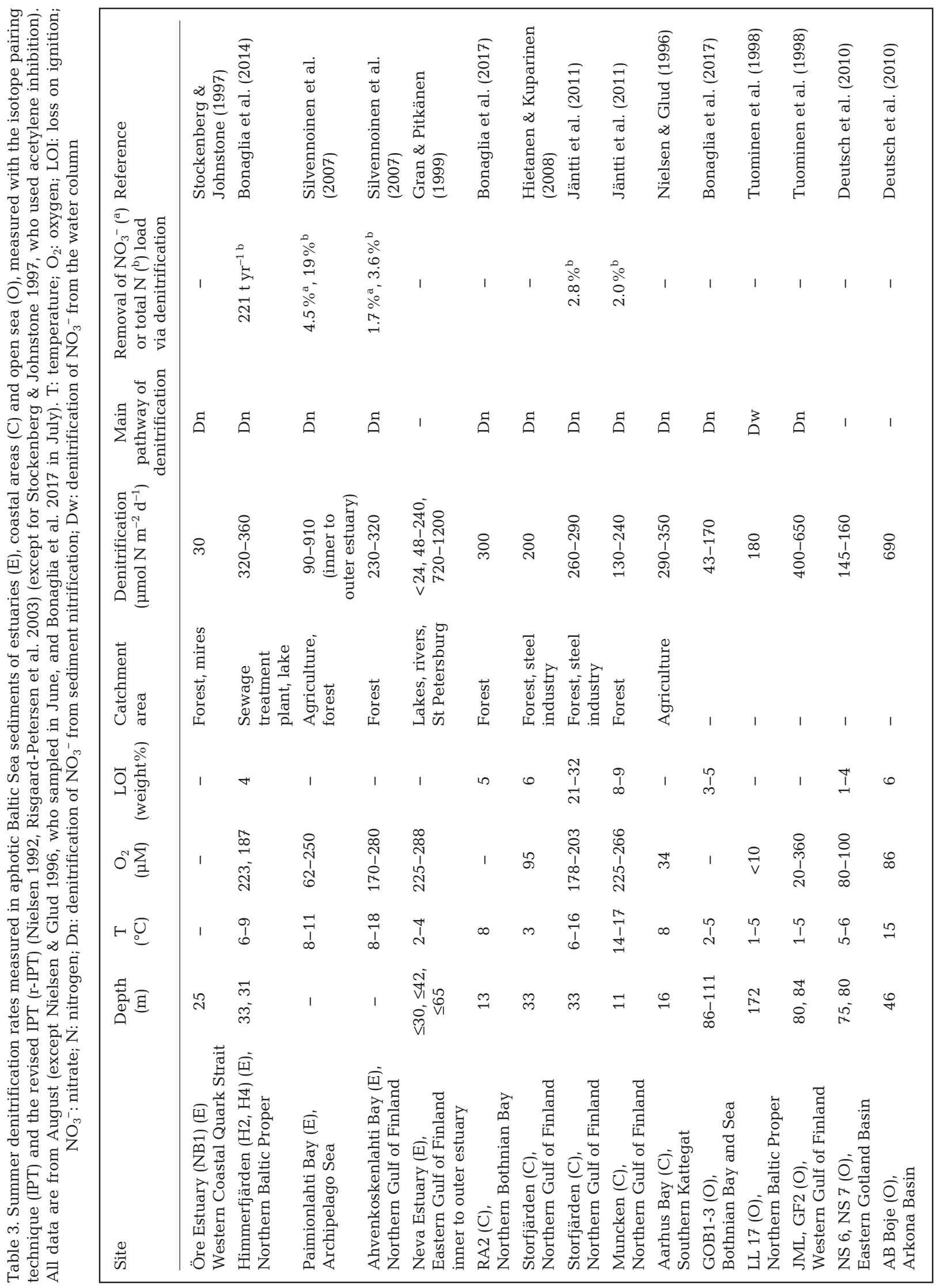


the mixing of fresh river water with brackish estuarine water, subsequently increasing the contact between river water and sediments, and enabling biogeochemical transformations (Nedwell et al. 1999). Furthermore, a long residence time increases the time available for $\mathrm{NO}_{\mathrm{x}}{ }^{-}$uptake by estuarine phytoplankton (Holmes et al. 2000). During the 2015 spring flood, the water residence time in the Öre Estuary was $\sim 3$ wk (C. Humborg \& A. Sokolov unpubl. data), and the river discharge formed a shallow freshwater plume that did not mix with estuarine bottom waters (Fig. 3). Consequently, the $\mathrm{NO}_{\mathrm{x}}{ }^{-}$load of the spring flood had no direct contact with the sediments. During low river discharge in August, the freshwater plume was thicker, but still did not mix with estuarine bottom waters due to additional thermal stratification (Fig. 3). Thus in both seasons, the major estuarine $\mathrm{N}$ source (riverine $\mathrm{NO}_{\mathrm{x}}^{-}$load) was uncoupled from its sink (benthic denitrification). The only link between $\mathrm{NO}_{\mathrm{x}}{ }^{-}$source and sink is phytoplankton PON that is formed during uptake of $\mathrm{NO}_{\mathrm{x}}{ }^{-}$from the surface plume, sinks out of the plume onto the sediment surface and finally releases $\mathrm{N}$ in benthic degradation processes. This way, riverine $\mathrm{NO}_{\mathrm{x}}{ }^{-}$is temporarily trapped in PON, mineralized to $\mathrm{NH}_{4}{ }^{+}$, nitrified to $\mathrm{NO}_{3}{ }^{-}$and eventually denitrified to $\mathrm{N}_{2}$ (coupled nitrification-denitrification). PON as a carrier of $\mathrm{N}$ from surface waters to the sediment has also been proposed in other studies (Jørgensen \& Sørensen 1985, Kemp et al. 1990, Holmes et al. 2000, Radtke et al. 2012, Finlay et al. 2013, Korth et al. 2013), with the ultimate fate of PON not only being denitrification (Holmes et al. 2000, Radtke et al. 2012, Finlay et al. 2013, Korth et al. 2013), but also burial (Finlay et al. 2013) and export to the open sea (Jørgensen \& Sørensen 1985).

During the 2015 spring flood, $70 \%$ of POM in the surface waters of the Öre Estuary was derived from riverine and estuarine phytoplankton (Table 2), which agrees with an establishing phytoplankton bloom during the time of sampling (L. Haragutchi pers. comm.). We assume that a fair amount of this autochthonous POM stayed in the estuary, as particle retention time is short in the plume but long in the estuary (Brydsten \& Jansson 1989), and the near bottom waters contained high concentrations of $\mathrm{N}$-poor and likely resuspended POM in August (Fig. 6). With Dn being the main denitrification pathway in the Öre Estuary and $\mathrm{N}$ burial likely negligible due to low organic matter loading, the riverine $\mathrm{NO}_{\mathrm{x}}{ }^{-}$load will be gradually removed as $\mathrm{N}_{2}$ well after the time of spring load.

We calculated the $\mathrm{N}$ removal by denitrification in the Öre Estuary in relation to the riverine $\mathrm{NO}_{\mathrm{x}}{ }^{-}$load for August 2015 with Öre River discharge (http://vattenwebb.smhi.se/station/) and $\mathrm{NO}_{\mathrm{x}}{ }^{-}$concentration data (http://miljodata.slu.se/mvm/), corrected for the upriver location of the measuring station (factor 1.05946; L. Sonesten pers. comm.). We assumed that denitrification rates were constant over the month and the entire soft sediment area, as denitrification rates did not show any trend with the river plume transect. We estimated a soft sediment area of $20.6 \mathrm{~km}^{2}$; the remaining area consisted of bedrock, moraine and coarse sediments (marine surface substrate data 1:100 000 (C) Geological Survey of Sweden, ESRI ArcGIS, ArcMap 10.3.1). In August, denitrification removed $1.21 \mathrm{t} \mathrm{N}$ from the estuary, which was $\sim 2.3 \%$ of the annual $\mathrm{NO}_{\mathrm{x}}{ }^{-}$load (54 t). Coupled nitrification-denitrification (Dn) removed $1.12 \mathrm{t} \mathrm{N}$, resulting in more $\mathrm{N}$ being removed than arrived in the estuary as riverine $\mathrm{NO}_{\mathrm{x}}^{-}$during the same month (0.37 t). Consequently, Dn must have removed mainly $\mathrm{N}$ from remineralized, accumulated PON, and the estuary can be seen as a sink of riverine $\mathrm{NO}_{\mathrm{x}}{ }^{-}$, temporarily incorporated in phytoplankton biomass.

Despite constantly increasing $\mathrm{N}$ loads, the amount of riverine $\mathrm{NO}_{\mathrm{x}}{ }^{-}$removal via denitrification in the oligotrophic Öre Estuary is not likely to increase accordingly, as primary production is not likely to increase due to the P-limitation of the estuary and the constancy in phosphate loading (Wikner \& Andersson 2012, http://miljodata.slu.se/mvm/). If the estuary stays oligotrophic, denitrification rates via Dn will stay constant and Dw is also not likely to increase due to the separation of riverine $\mathrm{NO}_{\mathrm{x}}{ }^{-}$in surface waters from the sediments by water column stratification. This could mean that in the future, more $\mathrm{NO}_{\mathrm{x}}{ }^{-}$ could be exported to the open sea, which would eventually decrease the $\mathrm{NO}_{\mathrm{x}}{ }^{-}$'filter function' of the estuary relative to the $\mathrm{NO}_{\mathrm{x}}{ }^{-}$load.

\section{CONCLUSION}

We suggest that the cohesive muddy and sandy sediments of the oligotrophic Öre Estuary function as a sink for riverine $\mathrm{NO}_{\mathrm{x}}{ }^{-}$via temporary incorporation of $\mathrm{N}$ in phytoplankton biomass (PON), which is later mineralized to $\mathrm{NH}_{4}{ }^{+}$, nitrified to $\mathrm{NO}_{3}{ }^{-}$and denitrified to $\mathrm{N}_{2}$. This sequence includes a time delay, which results in a mismatch between the time of highest $\mathrm{NO}_{\mathrm{x}}{ }^{-}$ load and highest $\mathrm{N}_{2}$ removal, with PON serving as a 'trap' of $\mathrm{NO}_{\mathrm{x}}{ }^{-}$. This 'filter function' is not likely to increase with increasing $\mathrm{N}$ loads, as the oligotrophic estuary is P-limited, which prevents an increase in primary production and a subsequent increase in 
sediment nitrification and denitrification (Dn). Hence, under continuously increasing $\mathrm{N}$ loading, the trophic state of the oligotrophic Öre Estuary is not very likely to change, but at the same time more $\mathrm{NO}_{\mathrm{x}}{ }^{-}$might be exported to the open sea.

Acknowledgements. We thank Daniel Conley for initiating and leading the field campaigns; Sanni Aalto and Iris Liskow for laboratory and analytical help; Anni Jylhä-Vuorio for assistance in the field; Jani Anttila and Eliecer Diaz for statistical advice; and Alexander Sokolov, Christopher Humborg, Heather Reader, Lumi Haragutchi, Lucie Kirchhoff and Tom Jilbert for valuable discussions. The Umeå Marine Sciences Centre provided valuable marine infrastructure, environmental monitoring data and laboratory support. Christophe Rabouille provided bottom water $\mathrm{O}_{2}$ data for April, and the Geological Survey of Sweden provided ArcGIS data for the sampling area. This project was supported by the BONUS COCOA project (grant agreement 2112932-1), funded jointly by the European Union and the Academy of Finland, the Chancellor's travel grant of the University of Helsinki and the Academy of Finland (projects 272964, 303774 and 267112). We thank 4 anonymous reviewers for their constructive criticism that helped improve the manuscript

\section{LITERATURE CITED}

Andersen JH, Conley DJ, Hedal S (2004) Palaeoecology, reference conditions and classification of ecological status: the EU Water Framework Directive in practice. Mar Pollut Bull 49:283-290

Bonaglia S, Deutsch B, Bartoli M, Marchant HK, Brüchert V (2014) Seasonal oxygen, nitrogen and phosphorus benthic cycling along an impacted Baltic Sea estuary: regulation and spatial patterns. Biogeochemistry 119:139-160

Bonaglia S, Hylén A, Rattray JE, Kononets MY and others (2017) The fate of fixed nitrogen in marine sediments with low organic loading: an in situ study. Biogeosciences 14:285-300

Boudreau B, Huettel M, Forster S, Jahnke RA and others (2001) Permeable marine sediments: overturning an old paradigm. EOS Trans Am Geophys Union 82:133-136

Brydsten L (1992) Wave-induced sediment resuspension in the Öre estuary, northern Sweden. Hydrobiologia 235: 71-83

Brydsten L, Jansson M (1989) Studies of estuarine sediment dynamics using Cs-137 from the Chernobyl accident as a tracer. Estuar Coast Shelf Sci 28:249-259

Burdige D (2006) Geochemistry of marine sediments. Princeton University Press, Princeton, NJ

Christensen PB, Nielsen LP, Revsbech NP, Sørensen J (1989) Microzonation of denitrification activity in stream sediments as studied with a combined oxygen and nitrousoxide microsensor. Appl Environ Microbiol 55:1234-1241

Dalsgaard T, Nielsen L, Brotas V, Viaroli P and others (2000) Protocol handbook for NICE-nitrogen cycling in estuaries: a project under the EU research programme: Marine Science and Technology (MAST III). National Environmental Research Institute, Silkeborg

Dalsgaard T, Thamdrup B, Canfield DE (2005) Anaerobic ammonium oxidation (anammox) in the marine environment. Res Microbiol 156:457-464
Deek A, Dähnke K, van Beusekom J, Meyer S, Voss M, Emeis K (2013) $\mathrm{N}_{2}$ fluxes in sediments of the Elbe Estuary and adjacent coastal zones. Mar Ecol Prog Ser 493:9-21

* Deutsch B, Forster S, Wilhelm M, Dippner JW, Voss M (2010) Denitrification in sediments as a major nitrogen sink in the Baltic Sea: an extrapolation using sediment characteristics. Biogeosciences 7:3259-3271

Diaz RJ, Rosenberg R (2008) Spreading dead zones and consequences for marine ecosystems. Science 321:926-929

*Dong LF, Thornton DCO, Nedwell DB, Underwood GJC (2000) Denitrification in sediments of the River Colne estuary, England. Mar Ecol Prog Ser 203:109-122

Dore MHI (2005) Climate change and changes in global precipitation patterns: What do we know? Environ Int 31: $1167-1181$

Dürr HH, Laruelle GG, van Kempen CM, Slomp CP, Meybeck M, Middelkoop H (2011) Worldwide typology of nearshore coastal systems: defining the estuarine filter of river inputs to the oceans. Estuaries Coasts 34:441-458

Dyer KR (1973) Estuaries: a physical introduction. Wiley \& Sons, London

* Engström P, Dalsgaard T, Hulth S, Aller R (2005) Anaerobic ammonium oxidation by nitrite (anammox): implications for $\mathrm{N}_{2}$ production in coastal marine sediments. Geochim Cosmochim Acta 69:2057-2065

* Eyre BD, Ferguson AJP, Webb A, Maher D, Oakes JM (2011) Denitrification, N-fixation and nitrogen and phosphorus fluxes in different benthic habitats and their contribution to the nitrogen and phosphorus budgets of a shallow oligotrophic sub-tropical coastal system (southern Moreton Bay, Australia). Biogeochemistry 102:111-133

*Eyre BD, Maher DT, Squire P (2013) Quantity and quality of organic matter (detritus) drives $\mathrm{N}_{2}$ effluxes (net denitrification) across seasons, benthic habitats, and estuaries. Global Biogeochem Cycles 27:1083-1095

Fenchel T, King GM, Blackburn T (2012) Bacterial biogeochemistry: the ecophysiology of mineral cycling, 3rd edn. Elsevier Academic Press, London, and Waltham, San Diego, CA

*Finlay JC, Small GE, Sterner RW (2013) Human influences on nitrogen removal in lakes. Science 342:247-250

* Forsgren G, Jansson M (1993) Sedimentation of phosphorus in limnetic and estuarine environments in the River Öre system, northern Sweden. Hydrobiologia 253:233-248

FForster S, Bobertz B, Bohling B (2003) Permeability of sands in the coastal areas of the southern Baltic Sea: mapping a grain-size related sediment property. Aquat Geochem 9: 171-190

Glud RN, Forster S, Huettel M (1996) Influence of radial pressure gradients on solute exchange in stirred benthic chambers. Mar Ecol Prog Ser 141:303-311

Glud RN, Gundersen JK, Røy H, Jørgensen BB (2003) Seasonal dynamics of benthic $\mathrm{O}_{2}$ uptake in a semienclosed bay: importance of diffusion and faunal activity. Limnol Oceanogr 48:1265-1276

* Gongol C, Savage C (2016) Spatial variation in rates of benthic denitrification and environmental controls in four New Zealand estuaries. Mar Ecol Prog Ser 556:59-77

* Goñi MA, Teixeira MJ, Perkey DW (2003) Sources and distribution of organic matter in a river-dominated estuary (Winyah Bay, SC, USA). Estuar Coast Shelf Sci 57: 1023-1048

Gran V, Pitkänen H (1999) Denitrification in estuarine sediments in the eastern Gulf of Finland, Baltic Sea. Hydrobiologia 393:107-115 
Hall S (2002) The continental shelf benthic ecosystem: current status, agents for change and future prospects. Environ Conserv 29:350-374

* Hedges J, Keil R (1995) Sedimentary organic-matter preservation-an assessment and speculative synthesis. Mar Chem 49:81-115

Hedges J, Keil R (1999) Organic geochemical perspectives on estuarine processes: sorption reactions and consequences. Mar Chem 65:55-65

HELCOM (2014) Eutrophication status of the Baltic Sea 2007-2011 - a concise thematic assessment. Baltic Sea Environ Proc 143. Baltic Marine Environment Protection Commission, HELCOM, Helsinki

*Hietanen S, Kuparinen J (2008) Seasonal and short-term variation in denitrification and anammox at a coastal station on the Gulf of Finland, Baltic Sea. Hydrobiologia 596:67-77

Holmes R, Peterson B, Deegan L, Hughes J, Fry B (2000) Nitrogen biogeochemistry in the oligohaline zone of a New England estuary. Ecology 81:416-432

Howarth RW, Billen G, Swaney D, Townsend A and others (1996) Regional nitrogen budgets and riverine N \& $P$ fluxes for the drainages to the North Atlantic Ocean: natural and human influences. Biogeochemistry 35: 75-139

Huettel M, Gust G (1992) Solute release mechanisms from confined sediment cores in stirred benthic chambers and flume flows. Mar Ecol Prog Ser 82:187-197

Huettel M, Ziebis W, Forster S (1996) Flow-induced uptake of particulate matter in permeable sediments. Limnol Oceanogr 41:309-322

Huettel M, Berg P, Kostka JE (2014) Benthic exchange and biogeochemical cycling in permeable sediments. Annu Rev Mar Sci 6:23-51

* Humborg C, Danielsson A, Sjöberg B, Green M (2003) Nutrient land-sea fluxes in oligothrophic and pristine estuaries of the Gulf of Bothnia, Baltic Sea. Estuar Coast Shelf Sci 56:781-793

Jahnke RA (2004) Transport processes and organic matter cycling in coastal sediments. In: Robinson AR, McCarthy J, Rothschild BJ (eds) The sea, Vol 13: the global coastal ocean. Harvard University Press, Cambridge, MA, p 163-192

Jäntti H, Stange F, Leskinen E, Hietanen S (2011) Seasonal variation in nitrification and nitrate-reduction pathways in coastal sediments in the Gulf of Finland, Baltic Sea. Aquat Microb Ecol 63:171-181

Jensen KM, Jensen MH, Kristensen E (1996) Nitrification and denitrification in Wadden Sea sediments (Königshafen, Island of Sylt, Germany) as measured by nitrogen isotope pairing and isotope dilution. Aquat Microb Ecol 11:181-191

Jilbert T, Asmala E, Schröder C, Tiihonen R and others (2017) Flocculation of dissolved organic matter controls the distribution of iron in boreal estuarine sediments. Biogeosciences Discuss, https://doi.org/10.5194/bg-2017181 , in review

Jørgensen B, Revsbech N (1989) Oxygen-uptake, bacterial distribution, and carbon-nitrogen-sulfur cycling in sediments from the Baltic Sea-North Sea transition. Ophelia $31: 29-49$

Jørgensen BB, Sørensen J (1985) Seasonal cycles of $\mathrm{O}_{2}$, $\mathrm{NO}_{3}{ }^{-}$and $\mathrm{SO}_{4}{ }^{2-}$ reduction in estuarine sediments: the significance of an $\mathrm{NO}_{3}^{-}$reduction maximum in spring. Mar Ecol Prog Ser 24:65-74
Kemp W, Sampou P, Caffrey J, Mayer M, Henriksen K, Boynton W (1990) Ammonium recycling versus denitrification in Chesapeake Bay sediments. Limnol Oceanogr 35:1545-1563

Korth F, Fry B, Liskow I, Voss M (2013) Nitrogen turnover during the spring outflows of the nitrate-rich Curonian and Szczecin lagoons using dual nitrate isotopes. Mar Chem 154:1-11

*Malmgren L, Brydsten L (1992) Sedimentation of rivertransported particles in the Öre estuary, northern Sweden. Hydrobiologia 235:59-69

* Mayer L (1994a) Relationships between mineral surfaces and organic-carbon concentrations in soils and sediments. Chem Geol 114:347-363

*Mayer L (1994b) Surface area control of organic carbon accumulation in continental shelf sediments. Geochim Cosmochim Acta 58:1271-1284

Middelburg JJ, Soetaert K (2004) The role of sediments in shelf ecosystem dynamics. In: Robinson AR, McCarthy J, Rothschild BJ (eds) The sea, Vol 13. Harvard University Press, Cambridge, MA, p 353-373

* Middelburg J, Klaver G, Nieuwenhuize J, Markusse R, Vlug $T$, Vandernat $F$ (1995) Nitrous-oxide emissions from estuarine intertidal sediments. Hydrobiologia 311:43-55

Mulder A, van de Graaf AA, Robertson LA, Kuenen JG (1995) Anaerobic ammonium oxidation discovered in a denitrifying fluidized-bed reactor. FEMS Microbiol Ecol 16:177-183

*Nedwell DB (1987) Distribution and pool sizes of microbially available carbon in sediment measured by a microbiological assay. FEMS Microbiol Lett 45:47-52

Nedwell DB, Jickells TD, Trimmer M, Sanders R (1999) Nutrients in estuaries. In: Nedwell DB, Raffaelli DG (eds) Estuaries, Vol 29. Academic Press, London, p 43-92

Nielsen LP (1992) Dentrification in sediment determined from nitrogen isotope pairing. FEMS Microbiol Lett 86:357-362

Nielsen LP, Glud RN (1996) Denitrification in a coastal sediment measured in situ by the nitrogen isotope pairing technique applied to a benthic flux chamber. Mar Ecol Prog Ser 137:181-186

Nielsen K, Nielsen LP, Rasmussen P (1995) Estuarine nitrogen retention independently estimated by the denitrification rate and mass-balance methods: a study of Norsminde Fjord, Denmark. Mar Ecol Prog Ser 119:275-283

Nixon S (1995) Coastal marine eutrophication-a definition, social causes, and future concerns. Ophelia 41:199-219

*Nixon SW, Ammerman JW, Atkinson LP, Berounsky VM and others (1996) The fate of nitrogen and phosphorus at the land sea margin of the North Atlantic Ocean. Biogeochemistry 35:141-180

*Posser JI (1989) Autotrophic nitrification in bacteria. Adv Microb Physiol 30:125-181

R Core Team (2014) R: a language and environment for statistical computing. R Foundation for Statistical Computing, Vienna

* Radtke H, Neumann T, Voss M, Fennel W (2012) Modeling pathways of riverine nitrogen and phosphorus in the Baltic Sea. J Geophys Res 117:C09024

Kasmussen H, Jørgensen BB (1992) Microelectrode studies of seasonal oxygen uptake in a coastal sediment: role of molecular diffusion. Mar Ecol Prog Ser 81:289-303

* Revsbech N, Jørgensen B, Blackburn T (1980a) Oxygen in the sea bottom measured with a microelectrode. Science 207:1355-1356

* Risgaard-Petersen N, Nielsen L, Rysgaard S, Dalsgaard T, Meyer R (2003) Application of the isotope pairing tech- 
nique in sediments where anammox and denitrification coexist. Limnol Oceanogr Methods 1:63-73

Risgaard-Petersen N, Meyer RL, Schmid M, Jetten MSM, Enrich-Prast A, Rysgaard S, Revsbech NP (2004) Anaerobic ammonium oxidation in an estuarine sediment. Aquat Microb Ecol 36:293-304

Risgaard-Petersen N, Meyer RL, Revsbech NP (2005) Denitrification and anaerobic ammonium oxidation in sediments: effects of microphytobenthos and $\mathrm{NO}_{3}{ }^{-}$. Aquat Microb Ecol 40:67-76

Rysgaard S, Risgaard-Petersen N, Nielsen LP, Revsbech NP (1993) Nitrification and denitrification in lake and estuarine sediments measured by the $\mathrm{N}^{15}$ dilution technique and isotope pairing. Appl Environ Microbiol 59: 2093-2098

Rysgaard S, Risgaard-Petersen N, Sloth NP, Jensen K, Nielsen LP (1994) Oxygen regulation of nitrification and denitrification in sediments. Limnol Oceanogr 39: 1643-1652

Rysgaard S, Glud RN, Risgaard-Petersen N, Dalsgaard T (2004) Denitrification and anammox activity in Arctic marine sediments. Limnol Oceanogr 49:1493-1502

Schlitzer R (2015) Ocean data view. Alfred Wegener Institute for Polar and Marine Research, Bremerhaven. http:// odv.awi.de

Schulz HD (2005) Quantification of early diagenesis: dissolved constituents in marine pore water, 2nd edn. In: Schulz HD, Zabel M (eds) Marine geochemistry. Springer, Berlin, p 73-124

Seitzinger SP (1987) Nitrogen biogeochemistry in an unpolluted estuary: the importance of benthic denitrification. Mar Ecol Prog Ser 41:177-186

Seitzinger S (1988) Denitrification in fresh-water and coastal marine ecosystems - ecological and geochemical significance. Limnol Oceanogr 33:702-724

Seitzinger S, Nixon S (1985) Eutrophication and the rate of denitrification and $\mathrm{N}_{2} \mathrm{O}$ production in coastal marine sediments. Limnol Oceanogr 30:1332-1339

Seitzinger S, Nielsen LP, Caffrey J, Christensen PB (1993) Denitrification measurements in aquatic sediments:

Editorial responsibility: Ronald Kiene,

Mobile, Alabama, USA a comparison of three methods. Biogeochemistry 23: $147-167$

Silvennoinen $\mathrm{H}$, Hietanen S, Lilkanen A, Stange CF, Russow R, Kuparinen J, Martikainen PJ (2007) Denitrification in the river estuaries of the northern Baltic Sea. Ambio 36: $134-140$

Slater JM, Capone DG (1987) Denitrification in aquifer soil and nearshore marine sediments influenced by groundwater nitrate. Appl Environ Microbiol 53:1292-1297

SMHI (Swedish Meteorological and Hydrological Institute) (2003) Djupdata för havsområden. Svenskt Vattenarkiv. Oceanografi 73. SMHI, Norrköping, p 84

* Stepanauskas R, Jørgensen NOG, Eigaard OR, Zvikas A, Tranvik LJ, Leonardson L (2002) Summer inputs of riverine nutrients to the Baltic Sea: bioavailability and eutrophication relevance. Ecol Monogr 72:579-597

Stockenberg A, Johnstone R (1997) Benthic denitrification in the Gulf of Bothnia. Estuar Coast Shelf Sci 45:835-843

Thibodeaux LJ, Boyle JD (1987) Bedform-generated convective transport in bottom sediment. Nature 325:341-343

*Trimmer M, Nedwell DB, Sivyer DB, Malcolm SJ (1998) Nitrogen fluxes through the lower estuary of the river Great Ouse, England: the role of the bottom sediments. Mar Ecol Prog Ser 163:109-124

* Tuominen L, Heinanen A, Kuparinen J, Nielsen LP (1998) Spatial and temporal variability of denitrification in the sediments of the northern Baltic Proper. Mar Ecol Prog Ser 172:13-24

* van de Graaf A, Mulder A, de Debruijn P, Jetten MS, Robertson LA, Kuenen JG (1995) Anaerobic oxidation of ammonium is a biologically mediated process. Appl Environ Microbiol 61:1246-1251

*Wentworth CK (1922) A scale of grade and class terms for clastic sediments. J Geol 30:377-392

*Wikner J, Andersson A (2012) Increased freshwater discharge shifts the trophic balance in the coastal zone of the northern Baltic Sea. Glob Change Biol 18: 2509-2519

Kumft WG (1997) Cell biology and molecular basis of denitrification. Microbiol Mol Biol Rev 61:533-616

Submitted: January 18, 2017; Accepted: October 5, 2017

Proofs received from author(s): November 7, 2017 